\title{
Neo-Calligraphy: Religious Authority and Media Technology in Contemporary Shiite Islam
}

\author{
MORGAN CLARKE \\ University of Manchester
}

Religious authority and its relation to the mundane, and especially to the domains of politics and the state, is a perennial issue of sociological and theological concern. Within the Islamic world, my focus here, this issue takes particular form, inflected through the powerful trope of the shari'ah (Arabic, shari'ah), most commonly glossed in English as "Islamic law," although God's right "way" through life potentially addresses every aspect of human life. This comprehensiveness, conjoined with the "openness" that the shari'ah's nominally divine and hence, in the final analysis, inscrutable source entails, has consequences for the ways in which one might imagine a state that grounded its legitimacy in following that right path. Brinkley Messick's (1993) monograph The Calligraphic State has provided a now classic exploration of such a polity in North Yemen, and its transformations under modernization. His analysis of these processes turns on a central image: the shift from a "calligraphic," that is, personalized form of "textual domination," drawing its authority from the endlessly open and interpretable field of "shari'ah discourse" (1993: 1-3), to the rationalized, impersonal authority of modern legal texts, fixed and

\footnotetext{
Acknowledgments: I would like to thank all those who have helped in my researches in Lebanon, especially those cited in the course of this article and most particularly Shaykh Muhsin 'Atwi, Hajj 'Ali Sammour, and Hajj Hamid al-Khaffaf. I also express my gratitude to Professor Talal Khodari and Tom Perry for their unfailing friendship, hospitality, and support. My thanks are due to Judith Scheele and Michelle Obeid for reading drafts of this paper and CSSH's editors and anonymous reviewers for many helpful suggestions. Many of the points I make here have been presented at seminars at Cambridge, Aberdeen, the British Academy, Yale, SOAS and Manchester and I am grateful for the responses of those participating. Needless to say, all errors and infelicities are entirely my own. The research, writing, and final reworking of this paper have been generously supported by an ESRC doctoral studentship at the University of Oxford, a British Academy Postdoctoral Fellowship at the University of Cambridge, and a Simon Research Fellowship at the University of Manchester.
} 
monopolized by state officials and symbolized, following the master metaphor, by uniform, rigid print.

In Messick's account, the "calligraphic state" turned into something else, "modernity" perhaps. ${ }^{1}$ But shari'ah discourse has seen a vigorous efflorescence in modern times, fuelled by the advent of print, mass education, oil revenues, new communications technologies, and the administrative capabilities of modernizing, centralizing states. Even if, then, the contemporary shari'ah has in large part been fundamentally restructured, "modernized" even (Griffel 2007: 12-16), through its "massification" (Eickelman 1992) and "functionalization" (Starrett 1998), and despite frequent attempts by state actors and others to monopolize its interpretation, its openness and interpretability remain. Equally enduring has been the need to tie particular interpretation to person, to a recognized authority. In this article I focus on some of the ways in which that personalization of shari'ah discourse is effected in a post-print, digital age. In particular, digital scanning techniques readily allow the reproduction and transmission of an authority's signature, seal, and handwriting where print did not. I call this "neocalligraphy," in reference both to its form, but also, following and developing Messick's master image, in reference to the distinctive openness and personalization of religious authority that these forms of textual authority betoken and facilitate. "Neo-calligraphy" stresses the novelty neither of the calligraphic itself nor of this openness and personalization, but rather that of the context of modernized nation-states, mass education, and mass media within and against which the tradition must be self-consciously maintained and developed (Asad 1986), and that of the technical structures through which these discourses are being elaborated, communicated, and transformed. ${ }^{2}$ In its overarching reference to an open and personalized domain of shari 'ah discourse, neo-calligraphy may thus encompass forms other than calligraphic text, but digital calligraphy is nevertheless its most potent sign. Neo-calligraphy, particularly the superabundance of authoritative religious discourse it stands for, offers a continuing challenge to the bureaucratic state. Or at least it reaffirms the enduring dilemma of the integration of the transcendental and the mundane, as against the final triumph of the latter in the form of disenchanted modernity.

My focus is on Twelver Shiite jurisprudence ( fiqh), and I draw on fieldwork among the Shiite communities of Lebanon. ${ }^{3}$ Lebanon's Shiites moved from obscurity and humiliation to front of stage in the latter half of the twentieth

\footnotetext{
1 I am caricaturing Messick's more nuanced account here, although Messick himself does note the somewhat schematic nature of his crisply drawn picture (1993: 254-55).

2 That is, I do not mean to suggest a return to an idealized vision of the tradition's past after a perceived rupture in it, but to describe the latest move in a history of continuity and change.

3 Fieldwork took place in 2003-2004 (about twelve months), and 2007-2008 (nine months), chiefly in Beirut, in a variety of settings, in particular, for the purposes of this article, in the various offices of major religious authorities and in Lebanon's shari'ah (family law) courts, where I worked with a number of judges both Sunni and Shiite.
} 
century, brought to political consciousness and institutional existence as a confessional entity by the Lebanese Iranian cleric Imam Musa al-Sadr in the 1960s (Ajami 1986). A largely peasant population under "feudal" or "tribal" dominion in the south and the Biqa " transmogrified into an urban proletariat centered on Beirut's southern suburbs. They were mobilized within Lebanon's communitarian politics first through the Sadr-founded paramilitary and political organization Amal (Norton 1987), and then its rival, the explicitly Shiite Islamist and Iranian Revolutionary-backed Hezbollah, which now stands as one of the most powerful political actors in Lebanon and the region as a whole (Norton 2007). ${ }^{4}$ An influx of money from Iran and religious tithes and donations from wealthy Lebanese émigrés and sympathetic Shiite magnates in West Africa and the Arab Gulf has led to a boom in religious institutions. These include charitable foundations such as orphanages and hospitals, educational establishments including religious seminaries, and Islamic publishing houses, all operating in what is a richly diverse and highly contested social and intellectual scene (Deeb 2006; Shaery-Eisenlohr 2008).

Shiite jurisprudence is something of a special though significant case within the wider context of Islamic legal thinking. Traditional structures of religious authority and pedagogy have in many respects proved more enduring than those in the Sunni Muslim world (Fischer 1980; Mottahedeh 1985; Gleave 2007a: 61-63; Griffel 2007: 12), although the religious politics of the Islamic Republic of Iran pose an important challenge in this regard (Khalaji 2006). Most important for our purposes here is the continued prestige of a relatively informal hierarchy of religious specialists culminating in a limited number of "sources of emulation" (marāji " [sing. marja ] al-taqlīd), whose opinions (fatāwa $\bar{a}$, sing. fatwā) "lay," unqualified Shiite Muslims ${ }^{5}$ may, and indeed on many readings must follow to be absolved before God (Walbridge 2001a; Gleave 2007a). These are drawn from the ranks of the mujtahids, those scholars nominally deemed qualified by their peers to exercise their own, independent legal reasoning (ijtihadd) in interpreting scripture. In Lebanon, at least three such marja's are widely followed: Ayatollah 'Ali al-Sistani, the highest-ranking scholar of the prestigious seminaries of Najaf, Iraq (but Iranian by birth), and probably the world's most followed Shiite jurist; Ayatollah 'Ali al-Khamene'i, Khomeini's successor as Supreme Leader of the Islamic Republic of Iran and Hezbollah's chosen authority; and Lebanon's own Ayatollah Muhammad Husayn Fadlallah, who I give particular attention to here. Of the three, I should say, only Sistani's status as mujtahid and marja 'is more or less uncontroversial. Given the importance of the relationship

\footnotetext{
${ }^{4}$ Many were, and still are, also drawn to non-confessional movements of liberation, especially communism, and, to a lesser extent and among elites, the more economically liberal and proWestern politics of the right.

${ }_{5}^{5}$ That is, Usuli Twelver Shiite Muslims.
} 
between "source" (marja) and "imitator" (muqallid), the ability to index the source of a statement as to the shari'ah is crucial, especially considering the potential political significance of the words of a man who may, in the case of Ayatollah Sistani for instance, command the religious allegiance of millions. ${ }^{6}$

I begin with a brief summary of Messick's important analysis of shari'ah discourse and the "calligraphic" imagery he employs to evoke a pre-modern Islamic world such as could just still be glimpsed in the highland North Yemen of the 1970s, "at the end of an era of reed pens and personal seals, of handwritten books and professional copyists, of lesson circles in mosques and knowledge recited from memory, of court judgements on lengthy scrolls and scribes toiling behind slant-topped desks" (1993: 1). I then shift to the very different setting of twenty-first-century Shiite Lebanon to focus on the intellectual output of Ayatollah Fadlallah. He employs many of the traditional modes of jurisprudence and pedagogy that Messick discusses to further a distinctly "contemporary" agenda. His often-radical jurisprudential and political positions are disseminated via an Internet service for the provision of replies to his followers' moral dilemmas, and a ubiquitous presence in the local and international media. The latter troubles those who would prefer religious authority to be less publicly engaged. I then contrast this with the approach of Ayatollah Sistani, often perceived as more of a "traditionalist," who, despite his previous reputation as a recluse, was thrust into prominence by the American-led invasion of Iraq. Given the potential for his word to make or break American's plans, his own economy of pronouncement left a vacuum that was filled with spurious reports. As Reidar Visser (2006) has pointed out and as I investigate further here, this led his offices to insist that only statements bearing their seal and signature were authentic, even if digitized and transmitted through the Internet media in which Sistani has proved to be a notable pioneer. This is, I argue, part of a broader pattern, and I adduce additional examples to substantiate my claim to have identified a phenomenon of more general interest_- "neo-calligraphy." Like Messick (1993: 3), I see my analyses of my particular Lebanese cases as being of wider comparative interest, not just as a contribution to "shari'ah ethnography" (Messick 2008) or the growing literature on the effects of new media upon Islamic and other religious discourses, ${ }^{7}$ but also to larger debates over the personalization and depersonalization of authority, religious and otherwise, the relations between such authority, notions of authenticity and the "author-function" (Foucault 1979), and the transformations of those relations under modernity and technological change. ${ }^{8}$

\footnotetext{
6 The opinions of Ayatollah Fadlallah notwithstanding (Hamiyah 2004: 121), such a figure can only, according to the vast majority of opinion, be male.

7 E.g., Eickelman and Anderson 1999; Hirschkind 2006; Meyer and Moors 2006.

${ }^{8}$ On the evolution of the signature, for instance, see Fraenkel (1992) and Fraenkel and Pontille (2006). Today's "electronic signatures" are cryptographic and numerical rather than calligraphic. The demand for such mechanisms, and their predecessors, has been driven in large part by the
} 
In Messick's account of pre-republican North Yemen, where the shari'ah was placed at the center of the organization of the state, this particular form and instance of "textual domination" was built upon and articulated through a distinctive notion of textual authority, distinct, that is, from the forms of textual authority constitutive of the modern nation state. In a literary and pedagogical culture shared across the pre-modern Islamic world, ${ }^{9}$ texts-be they those of scripture, or the derived texts of Islamic jurisprudence-were ideally embodied. They were mastered by students, memorized and then transmitted through recitation, following the paradigm of the Qur'an, a text that urges its own recitation (Eickelman 1978). Such texts originated in study circles in one of the centers of Islamic learning. A master scholar lectured to students who wished to learn from him; the students might transcribe his lectures and he could then correct the manuscript. Such lectures would often take the form of a commentary on an earlier work. In calligraphic form, the commentary might appear written in the margins of the master text, or between its lines. This culture of commentary points to the "openness" and "interpretability" of shari'ah discourse. Far from the rigidity assumed by European colonial scholarship, Islamic legal scholarship was (and remains) a field of ongoing debate, albeit one with its own limits. ${ }^{10}$ While the shari'ah, God's right path through life, is divine and perfect, human attempts to define that right path, the subject of the human science of Islamic jurisprudence (fiqh), are inevitably flawed and open to critique. The "calligraphic" mode in which this debate was recorded can thus be seen as imaging the necessarily personalized nature of such works of interpretation: they belong to their author, a more or less recognized authority. ${ }^{11}$ The open texture of this potentially infinite domain of personalized discourse is most powerfully and beautifully symbolized in Messick's account by the "spiral texts" particular to Yemen. In them,

need to authenticate financial transactions, where an impersonal exchange often depends upon a personal guarantee, from checks to credit cards (Hart 2007). Against my focus on non-state actors here, that is still more the case for the development of the bureaucratic state (Bourdieu 1997: 66, quoted in Latour 2004: 43, n. 37), first mechanized and now digitized, if variably so. Latour (2004: 43) cites a leading French government bureaucrat chiding "l'archaïsme des députés qui exigent toujours des signatures autographes là où la logique voudrait que l'on permette la machine à signer, curieux hybride permettant à la fois la délégation mécanique et le maintien du principe de l'autographie dans la mesure où l'encre coule bien du stylo de la personne autorisée sans être ni photocopiée ni préimprimée." While I focus here on the uses of digitally reproduced handwriting to authenticate documents, such reproductions might equally of course be perceived as inauthentic. Witness the controversy over U.S. Secretary of Defense Donald Rumsfeld's use of a machine to reproduce his signature on letters of condolence to the families of military personnel killed in action rather than signing them personally (Milbank 2004).

9 And beyond: see, for example, Carruthers (1990) on medieval Europe.

10 For the continuing vigor of commentary culture, see below, and Zaman (2002: 38-59).

11 On the evaluation of personal hand $(y a d)$, its relation to the (spoken) word ( $q a w l)$, and the relation between original manuscript and copy, see Messick (1993: 29-30). 
calligraphy spirals outwards in circular fashion rather than descending in defined lines. While this "open" style is reflected in many different genres of document, it reaches its most dramatic realization in the official correspondence of upper Yemen's ruling Zaydi Shiite imams. Early-nineteenth-century imams signed their correspondence to authenticate it, but later imams prefigured the transportable authenticity of technologies to come by following the Ottoman usage of individual seals. Such seals were filled with self-consciously ornate calligraphy (Messick 1993: 1-2, 15-36, 233-34, 242). ${ }^{12}$

Throughout the Islamic world, the age of modernity, whether represented by European colonial rule or non-European modernization efforts, as in the Ottoman Empire of which upper Yemen (as indeed Lebanon) was a far-flung part, came to challenge shari'ah discourse as the paradigm of right governance. The new gold standard of judicial administration was the European civil code, pre-eminently the Code Napoléon of 1804 . As has been extensively documented (e.g., Davison 1963), in the nineteenth century the Ottoman regime, under pressure from European expansion and intervention, undertook a series of modernizing reforms, the Tanzimat. This included a project to draft a shari'ah-derived code along the lines of the European civil codes, the Majallah of 1876. This code was to be "Islamic in content, but ... European in form" (Messick 1993: 54, quoting Liebesny 1975). It would have numbered sections, fixed by the Sultan's bureaucrats, and would be rationalized, accessible, and knowable in ways that the vast domain of Islamic legal texts, commentaries, and commentaries on commentaries, ever open to renewed interpretation but the preserve of an Islamic scholarly elite, was not. The vastness of the field of shari'ah discourse almost defeated the drafters of the code: the shari'ah was, they wrote, employing an image that resonates through Islamic rhetoric, "an ocean without shores" (Messick 1993: 54, quoting the Majallah). The "civilizing" of the law and administration, under Ottoman, colonial, and post-Ottoman and post-colonial regimes in much of the wider region, in fact went much further, in that it almost completely eliminated the shari'ah's formal role in the life of the state and replaced it with civil law and civil courts proper. The notable exception to this trend was the law of "personal status." Across much of the present-day Muslim world, nominal "shari'ah courts" have retained jurisdiction over family law alone. ${ }^{13}$

\footnotetext{
12 These points are paralleled for the Maghreb by Jacques Berque's earlier Essai sur la méthode juridique maghrébine, especially its first chapter, "Changements d'optique." "[A]utour des vieux poèmes mnémotechniques serpente l'infinie arabesque des gloses ... La façade synoptique de la page imprimée fractionne le flux du discours: les nouvelles oeuvres ... procéderont d'une logique nouvelle. En même temps que l'utilité du vers mnémotechnique disparait, cette spirale infinie du commentaire, qui dans le vieux style oratoire s'imposait tout naturellement, parait aujourd'hui gaucherie et lourdeur ... Non seulement changement d'expression, de manière, mais changement d'optique, de texture logique" (2001 [1944]: 281-83).

${ }_{13}$ As Talal Asad points out in his discussion of legal reform in colonial Egypt, family law abides not as the inviolate heart of Islam, but as a privatization of religion integral to projects of secularization (2003: 227-28).
} 
Legal reform took similar form in the Yemen Arab Republic that succeeded imamic rule after the 1962 revolution. Educational and bureaucratic modernization brought a final end to what was left of highland Yemen's "calligraphic state." This transformation was symbolized, following Messick's master metaphor, by the adoption of "straight texts" such as standardized forms with printed margins and lines, sometimes still filled by hand, but "even typed." Such forms were authorized with republican seals. Where the imamic seals bore the personal name of the imam, these carried a symbol and the name of the nation-state (Messick 1993: 236-37, 244-45). Also transformed were even more distinctively shari'ah-rooted institutions, such as the office of the muftī, who issues fatwas - general, non-binding but authoritative statements as to the shari'ah. The provincial mufti who Messick worked with in the 1970s embodied knowledge, and thus answered every question he was posed immediately without pausing to consult reference texts (1993: 138), but in the 1980s Messick (1996) found something different: "media muftis" with a radio show, who, faced with an individual query, far from responding with unmediated immediacy consulted their jurisprudential libraries at leisure, before crafting a reply broadcast to a mass audience.

\section{SHARI'AH DISCOURSE IN LEBANON}

The "calligraphic state," then, is no more. But I would argue that the calligraphic way, the ocean without shores, the open sea of interpretation, has not disappeared into the mists of the past, even if it has not been static in other respects. I want to start my exploration of what I will call "neo-calligraphy" with a notable example of the contemporary explosion in shari'ah discourse, the prodigious intellectual output of Lebanon's Ayatollah Sayyid Muhammad Husayn Fadlallah. ${ }^{14}$ A controversial figure, Fadlallah has often been characterized as the Lebanese Hezbollah's "spiritual guide," although that is at best a dated characterization. Born in the distinguished seminary city of Najaf, Iraq, in 1935, Fadlallah excelled within the traditional religious curriculum under such luminaries as Ayatollah Abu-l-Qasim al-Khu'i (d. 1992), senior cleric of the Najaf school. But while Khu'i was avowedly apolitical, Fadlallah was caught up in the more radical intellectual currents of the time, being especially close to Ayatollah Muhammad Baqir al-Sadr, the brilliant reformist scholar and intellectual founder of the Islamist Iraqi $\mathrm{Da}^{\text {' }}$ wah party, who was later executed by Saddam Hussein's regime (Mallat 1993). Fadlallah left for his father's native Lebanon in 1966 and emerged as a leading Shiite Islamist thinker and activist.

\footnotetext{
14 Ayatollah, "miraculous sign of God," is the highest of a hierarchy of religious titles that have relatively recently emerged in Shiite Islam (save for additional qualifications such as "grand ayatollah" [āyāt allāh al-'uzmā], which title Fadlallah et al. are also given) (Mottahedeh 1985: 232-33). "Sayyid" is another honorific frequently employed among the Lebanese Shiite community to refer to descendants of the Prophet Muhammad. Both the ayatollahs we focus on here, Fadlallah and Sistani, are sayyids, and I use both titles.
} 
He was instrumental in the education and politicization of a generation who would flock to the emergent Hezbollah in the 1980s under the shadow of Lebanon's civil war and Israeli occupation. Fadlallah continues to espouse radical and anti-imperial politics, but in recent years he has distanced himself from Hezbollah and its Iranian backers (Sankari 2005: 200-2, 267-68, 286-88), attempting to carve out a distinct role and a much grander vision of "resistance" founded on Islamic reform, the Third-Worldism of his youth, and a pronounced engagement with "the Other" (al-äkhar) (Sankari 2005; and Sukariyah 2007). This avowed "open-mindedness" (infitäh) has challenged and alienated some within the upper echelons of Hezbollah (Shaery-Eisenlohr 2008: 76, 154$55){ }^{15}$ The recipient of a very considerable income of religious tithes and donations, he stands at the head of a sizeable transnational network of charitable and educational institutions, ${ }^{16}$ has a radio station ("The good news" [al-bashā'ir]), and a busy website (www.bayynat.org.lb). He is a locally and indeed regionally respected political activist and commentator through the vehicles of his Friday sermons at al-Imamayn al-Hasanayn mosque in Beirut's southern suburbs, press statements circulated to major media outlets, and frequent television and newspaper interviews. According to his website, he has authored forty-three books for a general audience, including several collections of his poetry, as well as fifteen volumes of specialist jurisprudence, and a twenty-five volume work of Qur'anic exegesis. ${ }^{17}$ A separate series of transcriptions of his lectures in Damascus, to which he travels every week to teach, already runs to volumes in double figures.

Ayatollah Fadlallah is producing, then, a torrent of fiqh (Islamic jurisprudence). In the words of a high-ranking staff member, echoing the image we encountered above, "the sayyid is a sea" or ocean (al-sayyid bahr). One of his leading students, Shaykh Ja'far al-Shakhuri (2002: 5) describes his body of work as "overflowing with thoughts and lively perspectives ... a well-spring of jurisprudence in the contemporary Islamic legal intellectual desert," spiritual refreshment that is, in the words of another pupil, "fresh, bright, and sweet to its drinkers" (Firhan 2007: 8). This is an explicitly reformist jurisprudence, then, claimed to be exceptionally so. Since 1995, Fadlallah has been widely, if controversially and not universally, recognized as a marja ', and thus a "source" of authoritative shari'ah opinion. ${ }^{18}$ Again, those who have elected to follow the

\footnotetext{
15 Such "open-mindedness" is, I should say, hardly unqualified: witness his staunch, if regionally unexceptional, anti-Israeli stance that extends to critiques of "exaggerated" holocaust remembrance and endorsement of the March 2008 killing of Israeli seminary students.

${ }^{16}$ This charitable network, the Mabarrat Association, runs six orphanages, fifteen high schools, and three technical and academic training facilities, serving 17,500 students, as well as two hospitals, other medical facilities, and a chain of not-for-profit petrol stations and restaurants. In 2003 the association spent some U.S.\$7 million on its 3,500 orphans and 350 handicapped dependents (Deeb 2006: 88-90; El-Ghoul 2004; www.mabarrat.org.lb).

17 At http://english.bayynat.org.lb/Biography/index.htm\#book (accessed 21 Apr. 2009).

18 On the controversy over Fadlallah's candidacy, see Rosiny 2001, and Sankari 2005: 256-57.
} 
opinion of such an authority are absolved of responsibility before God for action consonant with it. A substantial collection of Fadlallah's responses to petitions for religious advice (2005a [1995?]) was construed by many to be a type of risālah 'amalīyah, the "practical treatise" or comprehensive legal handbook published by a marja ' for the benefit of his followers (Aziz 2001: 208). Fadlallah's preface to the second edition of the second volume actually referred to it as such (2005a, v. 2: 7, dated 1997). ${ }^{19}$ But he has since published a much more substantial three-volume work, "The jurisprudence of the shari'ah" (Fiqh al-shari'‘ah, Fadlallah 2002-2003), avowedly in the classic style, albeit rendered more accessible for its lay audience through explanations of the technical terms employed and the addition of material indicating the reasoning behind some of the rulings given. ${ }^{20}$ Thus, as was pointed out to me by a member of his staff, it is considerably larger than the norm. ${ }^{21}$

Though Fadlallah is a controversial marja', he is also a popular one in Lebanon and elsewhere, not least because of his eminently "contemporary" (mu'āsir) views, especially those that combat what his student Shakhuri (2002: 13) calls "the jurisprudential oppression" (al-idtihād al-fiqh $\overrightarrow{\text { ) }}$ of women. Specifically, he allows women the right to political participation, control over their own bodies and fertility, freedom to move outside of their marital home and undertake gainful employment with or without their husband's permission, and greater rights to obtain a divorce in extremis (Aziz 2001: 208-11; Fadlallah 2005b; Hamiyah 2004: 73-169). This contemporaneity, or "keeping up with the times" (muwākibat al- 'asr) as it is phrased locally, is one of the key poles around which turns the characterization of the relative merits of individual religious specialists. It is also central to a Lebanese Shiite reformist struggle against the perceived "backwardness" (takhalluf) of their community (Deeb 2006). ${ }^{22}$ The ethics of medical and scientific advance is one area where authorities can show their qualities in this regard, and one in which Fadlallah is commonly perceived as excelling (Clarke 2009: 191-97,

19 Ayatollah Khamene'i, whose claim to marja' status is also controversial, has published a similar volume which stands as his own risälah for the time being (Walbridge 2001b: 235-36; Clarke 2007: 291-92).

20 A fourth volume is mooted, according to my sources.

21 One of Fadlallah's most popular earlier jurisprudential works was his annotated edition (Fadlallah 1998, since reprinted) of the fatwas of Ayatollah Muhammad Baqir al-Sadr (see above), intentionally more accessible than the seminary standard, as indicated by its title, "Clear fatwas" (Al-fatāwa al-wädihah). One can equally in this respect place Fadlallah within a Lebanese Shiite reformist tradition (Mervin 2000), as in the very accessible jurisprudential works written for laymen by the distinguished Lebanese Shaykh Muhammad Jawad Mughniyah (d. 1979; see Mallat 1988). More broadly, the relatively recent (late-nineteenth-twentieth century) genre of the risälah amaliyah itself could be seen as catering to the needs of a growing educated lay public.

22 See also Abisaab (2006), and Shaery-Eisenlohr (2008), who stresses the contested nature of this project. Pace Deeb (2006), I prefer “contemporary" (mu 'āsir) to "modern” (hadìth, moderne), which has, amongst the Islamic scholarly classes I work with at least, negative connotations (of, I infer, radical disjuncture). 
passim). I asked one of the shaykhs working within Fadlallah's organization why he had chosen to follow Fadlallah, and his response was typical:

Cloning. I was [studying] in Qom when this issue first hit the news. I heard an interview with Sayyid Fadlallah - he talked about it in a scientific manner, explained how it worked-you take a cell, you empty it of its nucleus and so on. ${ }^{23}$ This was when some of the ulama didn't even know the meaning of the word. I was in Qom for fifteen years. I had a great deal of respect for the ulama there. They had purity, piety, religiosity - you could feel it when you sat with them. But conversely there is also a simplicity. I might be sitting with them one day and they might ask, "Where are you from?" "Lebanon." "Oh, what province is that in?" They thought it was a town somewhere in Iran! If you ask them for example what's happening in Bosnia, they have no idea. ${ }^{24}$ Not like the sayyid. He follows everything; he has an opinion on everything. Some marja s won't talk in front of the media. Sayyid Fadlallah shattered this barrier. He even has women journalists come to interview him. If you just sit somewhere and people send you questions, then you answer from a theoretical perspective. But someone who is among the people answers practically.

Despite having been the target of a number of assassination attempts over the years, Fadlallah does indeed appear amongst the people every week, health permitting, to deliver the Friday sermon from the pulpit of his capacious mosque, exhorting his audience to moral improvement, but more especially to political consciousness in a message also delivered to Lebanon's major news agencies by fax.

Fadlallah's engaged and progressive jurisprudence is not, however, mere populism. This is, so his followers would argue, a coherent and profound theological project firmly rooted in the Shiite tradition. Indeed, such adherence to the tradition is vital to the authority and legitimacy of Fadlallah's "contemporary" views; he has to look both ways, as it were. ${ }^{25}$ There is, then, a real iceberg of intellectual endeavor lying beneath his public pronouncements as to the shari'ah for his lay followers, which are often, as befits the genre, schematic, even if relatively more verbose than those of other authorities. A series of volumes has recently been published of transcripts of his lectures to his students, many of them senior scholars at the research (dars al-khärij) level in his seminaries in Beirut and Damascus. These give us invaluable insights into the philosophy and method behind his jurisprudence. ${ }^{26}$ Such "reports" (taqrī $\bar{a} t$ ) are historically conventional. Making them available in printed

${ }^{23}$ On Fadlallah's ready permission for human cloning, see Clarke (2009: 66, 85, n. 21). He is not unique in this.

${ }^{24}$ This is a partisan account: there are of course a great many "contemporary" clerics in Qom as well.

${ }^{25}$ Some might say that he tries to have it both ways at once, portraying himself simultaneously as both proponent and critic of revolutionary Shiism on the one hand, and of traditional seminarycentered culture on the other (Aziz 2001: 206-7).

${ }^{26}$ Space forbids a full exposition here, but Fadlallah in particular privileges the Qur'an over the riwäyah/hadith literature recording the ways of the Prophet and, for the Shia, the imams. This is consonant with a general attempt on Fadlallah's part to minimize Sunni/Shiite differences (Rosiny 2001). He also favors a jurisprudence situated within historical and sociological contexts (Husayni 2007b). 
form to a wider public is less so. Pedagogy often takes traditional forms, such as the commentaries on classic texts discussed by Messick, although the printed book requires a different format from previous calligraphic instances. Figure 1 shows the first two pages of Fadlallah's commentary (Shakhuri 1996) on the section on marriage (Kitāb al-nikāh) in Ayatollah Muhammad Kazim al-Yazdi's (d. 1918) classic jurisprudential work Al- 'urwah al-wuthqa, "The firmest tie." This is the prototype of the modern risālah 'amalīyah, the comprehensive legal handbook that a marja' must produce for his followers, and is a staple seminary text (Mervin 2000: 128; Walbridge 2001a: 5). Fadlallah's orally delivered commentary is here rendered in the form of massive, running footnotes to the main text. ${ }^{27}$ Where Fadlallah's students feel the need to add clarification there are further footnotes to the footnotes. While some of the other volumes in the series are commentaries on different sections of $A l$ - 'urwah al-wuthqa, some printed in this format and some not, one volume (Husayni 2002) takes the more unusual form of a commentary on sections of a twentieth-century work of "civil law": distinguished Egyptian jurist Dr "Abd al-Razzaq al-Sanhuri's (1895-1971) renowned Al-wasìt fi sharh al-qānūn al-madani ("Companion to the analysis of the civil law"). ${ }^{28}$ Again, on the printed page, the matn, the source text (here Sanhuri's), takes precedence, with Fadlallah's commentary in extended footnotes, and the editor's additions of references and comments in footnotes to the footnotes. Other volumes simply transcribe Fadlallah's lectures, frequently styled as works of "comparative jurisprudence" (fiqh muqārin) (e.g., Hamiyah 2000).

We have, then, a self-consciously reformist jurisprudence formulated and transmitted in a broadly traditional form, although print gives it a distinct shape on the page. ${ }^{29}$ Shaykh Shakhuri, Fadlallah's editor for Kitāb al-nikāh, notes in his introduction to the volume:

Some try to oppose this method, which is called technically "commentaries on texts" [shurūh al-mutūn], because it restricts research to issues which history has left behind hundreds of years ago, such as the issue of slaves and concubines; and they argue that it is better if research-level studies take up subject matter independent of another book, so that the research can be enriched with the issues that the age needs. Even if one does meet with this observation, our sayyid and teacher [Fadlallah] transcends it

\footnotetext{
27 In volume two (Shakhuri 2002), just one paragraph of the main text (Al-'urwah al-wuthqā), some nine lines, warrants a commentary that fills the entire volume and runs to 248 pages.

28 The ascription "civil" here needs some comment, since Sanhuri, the drafter of the much-imitated Egyptian civil code of 1948, frequently stated that his aim was the reinstallation of a modernized shari'ah, and at points in his codes avowedly pursued the synthesis of civil form with shari'ah-derived content. This was a more sophisticated version of what had been attempted in the Ottoman Majallah, although the "Islamicity" of the code is hotly debated (see, for example, Shalakany 2001). Al-wasit is in itself a sort of commentary on Sanhuri's own work.

29 One wonders if browser-style media will in time allow new forms here, where commentaries on commentaries on commentaries can be revealed through windows on windows, as in the superb searchable on-line Qur'ans available with recitation, tafsitr (exegesis), and translation into several languages (e.g., www.quranexplorer.com).
} 
كتاب النكاخ

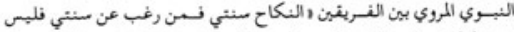

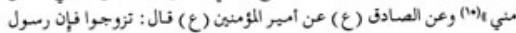

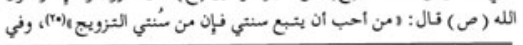

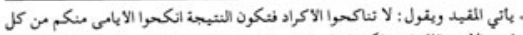

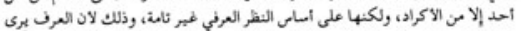

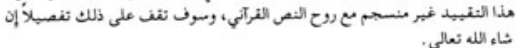

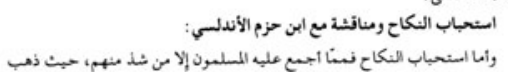

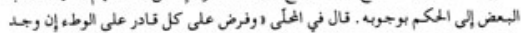

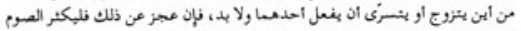

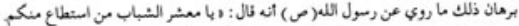

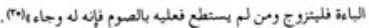

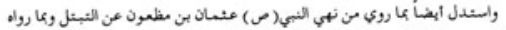

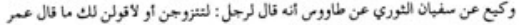

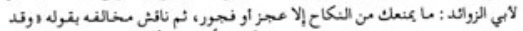

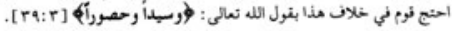

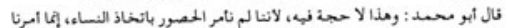

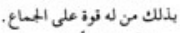

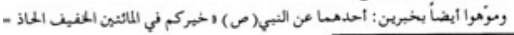

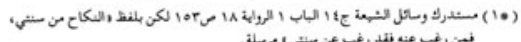

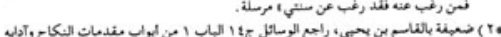

الرواية 14.

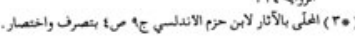

استحهاب البكاح النفيى

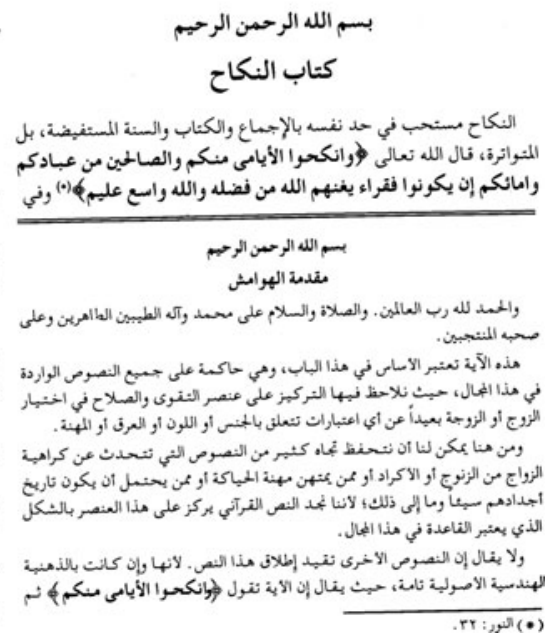

FIGURE 1 First two pages of Ayatollah Fadlallah's commentary on the "book of marriage" of Yazdi's Al- 'urwah al-wuthqā (Shakhuri 1996: 11-12). Above the heavy, doubled line is Yazdi's source text; below it is Fadlallah's commentary, with footnotes by his editor. Reprinted with permission.

by way of taking the text as orienting the research, and omitting the now theoretical issues and applications and adding subjects and researches that are important for the present time (Shakhuri 1996: 6).

Such new subjects and researches include, for example, a discussion of the admissibility of DNA evidence in a two-volume commentary on another section of $A l$ - 'urwah al-wuthqā, this time on the topic of judgment and the judiciary (qad̄̄') (Khishn 2007: 270-83). As Sabrina Mervin (2001: 86, citing Hasani 1994) reports, Fadlallah has himself stated his attachment to the traditional seminary (hawzah) educational system, and thus, one assumes, the study circle and the commentary culture. "There is a trend," Fadlallah is quoted as saying, "which considers ... the method of the hawzah, which leaves the student free, to be as far as pedagogy is concerned, the most modern method." Far from this being mere conservatism, then, "Fadlallah suggests that on these questions, Islamic tradition has anticipated the development of modernity" (Mervin 2001: 86). Nevertheless, while this is "recitational composition" (Messick 1993: 27), the sayyid's students gratefully acknowledge the boons of modern technology: "We have tried the utmost to preserve the words of our sayyid and teacher by using recording cassettes as a scientific means to eliminate errors as far as possible." Even so, consultation with the master 
remains indispensable: "There were some questions which were raised outside of the lesson, which I have inserted into the research lecture or in the margin, together with the reply of our teacher the sayyid (may God's protection of him endure)" (Shakhuri 1996: 8-9). Fadlallah acknowledges and authorizes such additions in his own prefaces, where he certifies that the reproduction of his lectures is indeed authentic and exact. Even if this jurisprudence is Fadlallah's responsibility and carried out in his name, its evolution is also in a sense a collaborative project.

\section{EN G A GEMEN T}

A similar mediation between "author," or rather "source" (marja ), and consumer occurs in the less elevated jurisprudential domain of petitions from the ayatollah's lay followers. These are received and processed by his consultation office (maktab al-istiftā'ät), nowadays mostly via his website, although his offices also receive telephone calls and sometimes visits in person. In 2004, in the course of earlier research on Islamic bioethics, I was fortunate to have an interview with the ayatollah himself, seated in a corner of the spacious reception rooms of his then Beirut offices, destroyed in the 2006 war with Israel. Our conversation was recorded, "in case you misunderstood him," but he talked freely and acutely (and with great patience) in response to my almost willfully abstruse questions about, for instance, analogies between surrogate motherhood and the "milk kinship" (rid $\bar{a}$ ) instituted under Islamic precepts through breast-feeding (Clarke 2009: 71-72, 125-33). The directness of his engagement and spontaneity of opinion were striking, reminiscent of the immediacy stressed in Messick's portrait of the muftis of the "calligraphic" age but all the more remarkable given the incomparably greater range and density of Sayyid Fadlallah's commitments. I was a frequent visitor to his offices, and I checked many points of detail with the head of the consultation department, Shaykh Muhsin 'Atwi. When Shaykh 'Atwi was unsure as to the sayyid's exact opinion, he would, where possible, ring the fons et origo himself to check.

Shaykh 'Atwi, too, receives telephone calls and personal visits from followers of the sayyid with problems to discuss. Most people, however, send their questions by email. These are printed out and translated if need be: many arrive in English and French, for instance. ${ }^{30}$ They are then brought to Shaykh 'Atwi, or to a more junior shaykhly colleague, sitting behind his desk in a characteristically modest office in what was, at the time of my visits in 2007 and 2008, the department's temporary home in an apartment block in South Beirut. A new and much better appointed building has since been constructed on the old site. The shaykh answers the questions in accordance with the opinions of Fadlallah's school,

\footnotetext{
30 These are sometimes from second-generation immigrants to Europe and North America, and even from converts, but they are also sent by Arabic speakers abroad whose computers are not Arabic-enabled. Clearly the process of translation raises further issues of mediation that would bear closer examination.
} 
usually off the top of his head. If necessary he consults the sayyid's published works of jurisprudence. These were then stacked amongst the works of other leading authorities, past and present, in great piles on the floor, but are now more commodiously housed on shelves in the department's new home. The shaykh scrawls the answers below the questions on the printed sheets with a biro, and toward the end of the working day (about 1:00 p.m., as in government offices) a lay functionary takes them to another office in the sayyid's organization. There they are typed up, translated if necessary, and sent back by email. This correspondence is compiled on a searchable database for reference purposes, and notable examples are posted on the website. For my work on bioethics (Clarke 2009) I requested a search for responses on assisted reproduction and received some fifty questions and answers dated between 2005 and 2008. Most were in Arabic but some were in French or English. This is not, one should note, the entirety of correspondence on the topic, since the compilers of the database seek to avoid repetition of content. If there is already a question on an identical matter then subsequent correspondence will not be recorded. The responses are numbered sequentially and my latest example was number 101,180 , which gives some idea of the scale of the phenomenon. Fadlallah's offices receive hundreds of thousands of petitions.

In this mass-mediated modality we have something superficially akin to the "media muftis" that Messick (1996: 320) opposes to the classical model: "Whereas the old logocentric textual culture sought the legitimating immediacy of a human presence to secure the authoritative transmission of knowledge, the new media intervene in a distancing and alienating manner. Instead of individualized communication, the new fatwas are broadcast messages for a mass audience." In our case, however, the contrast is not as stark since these are personal responses to personal requests (and some of them feature very personal information [e.g., Clarke 2009: 126-27, 129]), although some are posted on the website for the benefit of a larger audience. Crucially, the link to the original, authoritative source, here Fadlallah, is both essential and tightly maintained, by means of the mediating machinery of his offices and website. Indeed, some of the correspondence formally assumes a personal interchange with the sayyid himself: "I am one of your followers [anā min muqallid-kum]..."; or even, more boldly, "In which country did you obtain permission to practice ijtihād [interpretation of scripture] and who gave it to you?" The reply to the latter, a lengthy, eleven-line account of Fadlallah's scholarly credentials, is clearly labeled, "Answer of the office of His Eminence the Sayyid," and none of the correspondence under the heading "consultations" or "requests for fatwas" (istifta ' $\bar{a} t$ ) on the website's Arabic pages ("Q \& A" in the English section) is styled as a personal response from the ayatollah. Most of the petitions are in fact, and less naively, impersonally addressed, although, again, they are hardly impersonal in subject. Take just one example: "Is plastic surgery allowed in Islam? I don't like my face and I want to make some alterations to 
increase my confidence and well-being." The reply, a characteristically "understanding" one, reads: "Plastic surgery is not forbidden [according to "our", i.e., Fadlallah's school, we understand] if it does not entail another prohibited act or harm such as direct touch of a woman's body by a man or seeing the private parts." Fadlallah's address is not just to Shiite followers, or even just to Muslims, interested though he is in rapprochement between Shiism and Sunnism: it is universal. Consonant with this general stance of open engagement, the office's policy is to answer any query. Take this example, courtesy of the database: "My Mom says that God loves me and wants all people to go to heaven. Your Religeon says that Im a Infidel that should die [sic]. Why do you want to kill people for Allah?" The reply patiently explains that Islam holds that it is wrong to kill people and that Christians and Jews go to heaven too. ${ }^{31}$

This torrent of open, engaged jurisprudence is deeply worrying to some within the Shiite religious establishment: as a marja', a source of authoritative opinion, what Sayyid Fadlallah says is "law," as it were, or could at least be taken as a fatwa, an official statement of that authoritative opinion. And he says a very great deal. Barely a day goes by without a television interview, a press release, or even a letter to incoming American president Barack Obama, posted on the website alongside a new (and in this case explicit) fatwa legalizing the consumption of certain shellfish, and consolidated by an interview with Reuters (Perry 2009). Even the programming on Fadlallah's radio station is nominally reflective of his opinion, as the head of the station Hajj 'Ali Sammour told me. ${ }^{32}$ This leads to further dilemmas: That day a medical company had contacted Hajj Sammour wanting to claim in their advertising to be endorsed by the station, "to take shar 'iyah [(religious) legitimacy] from us. But we don't know anything about them!" However, engagement has its limits: Fadlallah has absolutely no wish to take on a potentially compromising state role in Lebanon, to be, as they say, a muwazzaf, a government functionary, and his initial enthusiasm for Khomeini's "guardianship of the jurisprudent" (wilāyat al-faqīh) over the running of the state has not survived the subsequent history of the Islamic Republic unqualified. 33 "Islamic

31 The first three examples are from the istiftā' $\bar{a} t$ section of the (Arabic) website: http://arabic. bayynat.org.lb/ahdathwakadaya/index.aspx, accessed 20 May 2009. The last is fatwa no. 71,720 from the database, dated November 2007 and quoted in its original English.

32 Interview, 12 June 2008.

33 Despite his early support of Khomeini's formulation (Sankari 2005: 276), Fadlallah moved to allowing the possibility of multiple "guardian jurisprudents" for distinct regions with distinct concerns (Aziz 2001: 212). He has since, according to one punning (and high-ranking) source I spoke with, abandoned the notion altogether in favor of the rule of law (wilāyat al-fiqh) over that of the jurist (wilāyat al-faqīh). Nevertheless, the latest editions of his published works still give a potential plurality of guardian jurisprudents general, if qualified power over political, economic, social, and security matters, subject to election by majority and consultation with a panel of technical experts, in parallel with favorable characterizations of democracy and political pluralism (Fadlallah 20022003, v. 1: 17-19; 2009: 31-37; http://arabic.bayynat.org.lb/ahdathwakadaya/qa.aspx?id=29, accessed 13 Oct. 2009). 
government" (al-hukümah al-islämīyah) remains in theory a proper-if somewhat vague - ideal, but not one to be pursued in practice, in Lebanon at any rate.

Nevertheless, the sheer weight that the word of such an independent authority carries may distort the nominally level political plane on which the bureaucratic state presumes to operate. This can be seen from the workings of the Lebanese family law system, under the exclusive jurisdiction of religious courts, Muslim and Christian. ${ }^{34}$ Even the possibility of a Shiite cleric serving as a judge is theologically contentious: in a world conceived as deprived of the perfect justice of the Hidden Imam, the divinely guided, sinless ruler who will return to rule at the end of days, to engage with the state before his return is in some sense necessarily to risk corrupting oneself (Gleave 2007b). While the Lebanese Shiite courts seem to get by in this regard, the worries of individual judges notwithstanding, some matters are weightier than others. A Shiite wife seeking a divorce from her husband without his consent, for instance, needs "the legitimate judge" (al-hākim al-shar 't) to rule on her case, and under majority Shiite opinion only the very highest religious authorities, the marāji ', qualify as being of sufficient moral acumen. Clearly that will be problematic within the context of the Lebanese courts since someone of such status will hardly wish so obviously to serve as a civil servant. Ayatollah Fadlallah, who should have the right as a widely acknowledged marja ', is in any case out of favor with Lebanon's Shiite establishment, who are suspicious of his claim to the marja 'iyah and dislike his activist style. But, characteristically, Fadlallah's opinion on this matter is considerably more "open-minded" than the juridical norm. It would in many cases be easier for women in such a position to obtain a ruling of divorce from Fadlallah than it would be in the courts. ${ }^{35}$ Indeed, Fadlallah has his own "court," or judicial office (maktab al-qad $\bar{a}^{\prime}$ ), where such cases and other disputes, chiefly financial, are heard by one of his shaykhly staff, Shaykh 'Ali Mir'i, although not, I should say, in conscious rivalry with the state courts. ${ }^{36}$ In $2007-2008$, this office was in the same building as the fatwa office, just across the landing, and

\footnotetext{
${ }^{34}$ See Rabbath 1986. Civil marriages contracted outside of Lebanon are subject to the civil courts.

${ }^{35}$ According to strict conditions and only in certain circumstances, of course. The difference turns on Fadlallah's readier recognition of women's rights to sexual fulfillment within marriage and of their fears for their virtue where they are denied those rights by, for instance, an absent husband (Hamiyah 2004: 113-14). This is a common scenario in Lebanon, where much of the country's male population travels abroad to seek their livelihood, frequently founding completely new lives and households.

36 As Shaykh Mir'i made clear, while from a religious perspective this "(religio-)legal office" (maktab shar 'î) can be termed a court (mahkamah), it has no such state legal status and no executive powers. The exception is if the parties concerned go to the public notary ( $k \bar{a} t i b$ al- $a d l)$ and draw up a ruling, which could, in financial disputes at least, be taken to a civil court for execution. He has about four appointments a day, five days a week, although not all for different cases, which is very considerably less than one finds in the state religious courts, let alone the civil courts.
} 
somewhat more comfortably furnished although cozy in size. ${ }^{37}$ As in the state courts, though on a more modest scale, a few black leather-look easy chairs sit by the shaykh's desk, and a calligraphic wall hanging appropriately cites a Qur'anic verse on the right treatment of wives. Unlike the state religious courts, a small portrait of Sayyid Fadlallah hangs above the judge's head, reminding us of the personalized authority on which the office depends. Statements and evidence are taken and compiled and, unless Shaykh Mir'i can dispose of the matter himself, the files sent to Sayyid Fadlallah who may himself meet with the parties concerned. ${ }^{38}$ Regarding a judicial divorce, if he is satisfied with the woman's case he then gives Shaykh Mir'i the permission to divorce her (ijāzat al-talāq). A ruling of divorce from the sayyid's offices, while satisfying the demands of religious and social propriety, for his supporters at least, is less easily validated with the state. While there are judges sympathetic to his open-minded jurisprudence, the Shiite Supreme Court is not, although in this particular matter relations appear to have become somewhat smoother of late. Rather, the Lebanese Shiite establishment recognizes as the greatest marja ' of the age Ayatollah 'Ali al-Sistani of Najaf, Iraq, who is commonly perceived as a more "traditional" figure. When its titular head Shaykh 'Abd al-Amir Qabalan pronounces such a divorce, he does so as Sistani's agent (wakil), specially authorized so to do. Even for the courts, then, the bureaucratic formally depends on the personal, even if the two claims to authority do not sit happily together.

\section{SIGNED AND SEALED}

This brings us neatly to my second example, that of Ayatollah Sistani. He is, so far as one can tell, currently the world's most widely recognized claimant to the title of "the most learned" (al-a 'lam), that is, the most senior of the marja 's, the summit of a nominal Shiite clerical hierarchy. There is an informality, and contestability, to this ascription, indeed to the very possibility of such a position, and Sistani himself does not explicitly claim it. However, on many traditional formulations, a lay Shiite should take as his marja " "the most learned," and it would seem that Sistani is both the most followed marja ' in the contemporary Shiite world ${ }^{39}$ and the most senior cleric within the seminaries of Najaf, the successor to Ayatollah Khu'i. This is a man of the traditional religious establishment who commands the loyalty of literally millions of followers and immense financial and institutional resources. Mehdi Khalaji (2006: 9) estimates his annual income at \$500-700 million and his worldwide assets at

37 At the time of writing I have not yet visited the suite in the new building.

38 He used to do this frequently, having performed the role of "judicial recourse" (marja 'iyah qada' 'yyah), especially in marital matters, for more than forty years. He only began to delegate such obligations to his representatives in the early 1980s, according to his website: http://arabic. bayynat.org.lb/sira/moassasat.htm, accessed 13 Oct. 2009.

39 According to Khalaji (2006: 6-7), he holds this distinction by quite some margin. 
over $\$ 3$ billion, and he has offices across the world (Rahimi 2007: 5-8). But, by contrast with, say, Fadlallah, Sistani famously almost never stirs from his simple room in a small house in a side street in Najaf. His public statements are tightly rationed, he has never given an interview to the media, and save one or two official portraits he does not suffer to be photographed. His reticence and reclusion were all too understandable under Saddam Hussein's regime, when the Shiite clergy were frequently heavily persecuted, especially after the 1991 Shiite uprisings in the wake of the first Gulf war. As Saddam's hand became steadily more oppressive, Sistani ceased not only public appearances at his mosque, but even his teaching circle. Thus, although his marja ship was announced in 1992, his religious and intellectual positions were not widely known (Khalaji 2006: 4, 8, 12). He has published a number of books available to his followers worldwide, most importantly his own risälah 'amalìyah, or comprehensive handbook, Minhāj al-sālihin ("The path of the righteous," Sistani 2002), as well as, for example, guides for Shiites living in the West (Sistani 2000). ${ }^{40}$ Still, in comparison with the voluminous publications of someone like Sayyid Fadlallah, his output has as yet been relatively restricted.

Sistani's comparative obscurity did not survive the American invasion of Iraq in April 2003. He was suddenly catapulted to global attention when the extent of his potential influence over Iraq's Shiite population became clear. Initially at least, his economy of public pronouncement and engagement continued, ${ }^{41}$ leading commentators and American officials to hail him as a "quietist," who held that religion and politics should be kept firmly separate, in keeping with his rejection of Khomeinism. ${ }^{42}$ This ready assumption was shattered when Sistani intervened in a major fashion, starting in the summer of 2003, by calling for an elected assembly to govern Iraq as against an Americanappointed one, and for general elections as against restricted ones in an explicit call for democracy that has attracted much comment. ${ }^{43}$ When, in an American policy retreat, elections were eventually scheduled, Sistani issued a fatwa enjoining registration on the electoral roll. Many Shiites took this to imply that voting was a religious duty. Challenged in his own domain by the antitraditionalist Sadrist movement and American attempts to crush it through a

40 More recently he has published an annotated edition of Yazdi's Al- 'urwah al-wuthqā ('A. Sistani 2007), considerably less luxuriant in its foot-noted commentary than the examples I have considered here.

41 He did issue some important early fatwas that enjoined respect for government property and prohibited retribution against agents of the previous regime without due process. It has been suggested that Sistani counseled against resisting the United States-led coalition forces, and this has been much debated and officially denied (Luizard 2003: 113-15; Visser 2006: 9-10).

42 That is, his rejection of Khomeini's interpretation of wilāyat al-faqīh. However, Sistani's position on the proper relation between religious authority and the state is clearly more engaged than the notoriously apolitical stance of his mentor Khu'i (Visser 2006: 13-15).

43 E.g., Cole 2006; Visser 2006; Rahimi 2007. 
siege of Najaf, he brokered a ceasefire in August 2004. After the end of 2004, however, his offices returned to a relative silence, most tellingly during the 2005 elections themselves, when there was a manifest demand for his guidance (Visser 2006: 2-3, 16).

This sudden burst of political engagement followed by withdrawal confused outside observers (ibid.). The miscomprehension extended to his interactions with the global media: Sistani's economy and style of speech during the immediate aftermath of the American invasion and beyond did not suit the demands of the twenty-four-hour news cycle, as Sistani's only official media spokesman Hajj Hamid al-Khaffaf told me in the ayatollah's Beirut offices shortly after the launch of a definitive compilation of Sistani's fatwas and statements concerning "the Iraqi question" (Khaffaf 2007). ${ }^{44}$ "In today's media, the press wants statements all the time, every day. That's not the sayyid's way." Fatwas, then, are not sound bites. But the media vacuum had to be filled, even if with the spurious. Journalists flocked to voluble "sources" against whom Sistani's office was forced to caution: "The various media have persisted in recent times in publishing political statements and analyses by people accorded diverse titles such as 'Sistani's representative' and his 'assistant' and 'agent,' among others. And most of these have no relation to him in this respect at all, and are not familiar with the views of His Eminence" (ibid.: 86). Most often such figures were Sistani's shaykhly wakils ("representatives", "agents"). One can see the attraction of such a title for a news network, but it is misleading. Wakils act for one or more of the great marja $\mathrm{s}$ in more or less limited capacities such as collecting and dispensing religious tithes on the ground, ensuring that the marja's charitable concerns are being properly run, and communicating his positions on religious matters of everyday concern. While a few are high-level scholars, as was Fadlallah when he acted as Khu'i's representative in Lebanon, for instance, the majority are not. Indeed, many are not even disciples of the marja " they nominally "represent," and they may represent several such authorities and have no knowledge of their views beyond what they can garner from a consultation of their definitive legal handbook (Visser 2006: 3-4).

This babble of unrepresentative "representatives" filling the media with unwarranted claims and suppositions regarding Sistani's stance on matters of vital concern had to be combated - this particular sea of interpretation was rather too open - and such was the purpose of Sistani's Iraq volume, as Khaffaf, its editor, states in the introduction:

44 This was in an interview on 22 May 2007. Mr. Khaffaf kindly agreed to another interview on 18 April 2008 that I also refer to here. Both took place in Sistani's then relatively modest offices in an apartment block in southern Beirut. An impressively large new building, to house a cultural center and library in addition to reception rooms and an office for shari'ah consultations, was then under construction and was newly opened on the occasion of my last visit in 2009 . 
The chief reason which impelled us to publish the book was to present the opinions of the most high religious authority [al-marja 'îyah al-dīniyah al-'ulyā; i.e., Sistani] regarding the political process, in accordance with what issued directly from that authority: in an attempt methodically to authenticate that, on the one hand, and to restrain the campaign of falsehoods and fabrications against the religious authority, on the other-a campaign which now and then ascribes to it specious and iniquitous statements and proclamations, with the aim of blackening its reputation and confusing the political situation. And what is odd is that, despite the fact that the office of His Eminence Sayyid Sistani has denied many of these lies and emphasized the necessity of establishing and adhering to what has been issued by His Eminence, signed and sealed with his noble seal, or written and sealed with the seal of his office, may God's protection of him endure, many media agencies keep on repeating these lies and calumnies! (Khaffaf 2007: 5).

The book thus presents all of these official statements, which are, as Khaffaf pointed out to me, relatively few: ninety-seven, over more than three of the most turbulent years in the country's history. They are presented first in chronological order, then again arranged by topic, and finally in their original form, digitally scanned. The book ends with a lengthy appendix contributed by Muntada al-Fikr al-'Iraqi ("the Iraqi thinkers' club") rebutting, page by page, the claims of Paul Bremer, former head of the Coalition Provisional Authority, in his Iraq memoir (Bremer 2006), to have enjoyed shared goals and collaboration with Sistani and his offices. Citing the appendix during our interview, Khaffaf marveled that Bremer had himself sent in an email question to Sistani's website rather than trying to arrange some more direct means of contact: but perhaps for a contemporary American bureaucrat email just does seem the most direct means of communication possible.

About a third (thirty-five) of the documents reproduced are replies to requests for a fatwa, either from an unnamed "group of the faithful," or from named parties. Besides the important fatwas regarding the constitution and elections, ${ }^{45}$ we have, for instance, a query from the Iraqi ambassador to Tehran asking about the legitimacy of clerics attempting to intervene to speed up the awarding of visas (forbidden: "You must apply the directions of your legal sources and not use the powers granted you in ways that breach equity between those resorting to you and give a bad reputation to embassy workers."); and one from the ministry of electricity asking if it is legitimate for people to purloin electricity from the national grid, or for those with the means to run unnecessarily large quantities of lights and appliances (both forbidden) (Khaffaf 2007: 134-35, 138-39). Just under a third (twenty-eight) are replies to the requests of various media outlets, American, European, Japanese, Arab, and Iraqi, for statements regarding a variety of issues. These range from what Sistani's position is regarding the interim governing council, to whether he fears for his personal safety and what his daily routine is. The question and answer format is often not radically different from those items of

\footnotetext{
45 These have been well analyzed by others (e.g., Luizard 2003; Visser 2006).
} 
correspondence labeled in the book as "requests for fatwas" (istiftā' $\bar{a} t$ ), and some journalists (often local correspondents, no doubt) take the trouble to undertake their letter "in the name of God" (bismillāh), address it to his "Eminence" (samāhah), and wish peace upon him (al-salām 'alaykum), which further confuses the genres. But these are carefully distinguished in the book as "questions [as'ilah] from Reuters [or Agence France Presse, Der Spiegel, etcetera]," as opposed to requests for fatwas proper, although, in a blurring of lines kept very distinct in the book, Juan Cole (2006: 13, n.16) cites one such correspondence, with Anthony Shadid of the Washington Post, as posted on Sistani's website as "Fatwa for Anthony Shadid." As I noted regarding Fadlallah's voluminous public output, the fatwa genre is not always as clear-cut as one might like, as an analyst, or even as a mufti. Most of the rest of the documents are either announcements (bayānāt) of one kind or another (twenty in number), or letters to named parties (thirteen) such as Hosni Mubarak, Kofi Annan, "the Iraqi people," and Cardinal Angelo Sodano, Secretary of State for the Vatican. ${ }^{46}$ The vast majority (eighty-six out of ninety-seven) are issued by "the office of Sayyid Sistani"; one is signed (but not sealed) by his son Sayyid Muhammad Rida Sistani (a reply to a letter addressed to him personally), two by his press spokesman Hamid al-Khaffaf, and one by an unnamed "official spokesman." Only seven are signed by Sayyid Sistani himself. "It depends on the importance of the matter," Khaffaf told me. "So we see that, for example, the fatwa regarding the constitution is in his name: because this was a very dangerous issue."

\section{N E O - C A L L I G R A P H Y}

The book is clearly a document of considerable historical importance that deserves much closer analysis, but for our purposes here I am most interested in the insistence on the signature and seal of Sistani himself, or his office, as the means of authentication. ${ }^{47}$ This is made abundantly clear in a number of the official public interventions collected in the volume: "Nothing is to be considered as the view of His Eminence the Sayyid (may His protection of him be prolonged) except what is issued signed and sealed with his noble seal or written and sealed with the seal of his office" (Khaffaf 2007: 70, 86; and see Visser 2006: 6). This stress on the Ayatollah's signature and seal absolutely marks a "calligraphic," personalized relation to law, albeit in the context of what I am venturing to term the "neo-calligraphy" of the digital age. In such uncertain times, the recognition and policing of individual personality is vital, even for religious authorities in the classic, unworldly, and self-effacing

\footnotetext{
46 The letter to Sodano was in commiseration at the death of Pope John Paul II. While hardly Iraq-related, it was, I assume, included due to its diplomatic and hence "political" nature.

47 The use of seals by such figures for the validation of texts is not in itself a novelty of course. See Mervin (2000: 127) for nineteenth- and early-twentieth-century instances.
} 
mould such as Sistani. The right to interpretation cannot be left wholly open. The volume very helpfully reproduces the documents themselves, digitally scanned where necessary, so that, one assumes, we can confirm that the fatwas and statements in Sistani's name are indeed in his hand, signed and sealed with his personal seal, as in the case of his important fatwa on the proposed Iraqi constitutional council (fig. 2). In a parallel, albeit less distinguished case, I myself requested a fatwa by email to Sistani's own, very impressive website (www.sistani.org) in the course of my bioethical researches. A reply came in the form of a GIF graphics file sent by the Internet office, based in Qom, Iran; that is, an image of my printed question with the handwritten reply (in Farsi) below, with the accompanying seal of the office (fig. 3). ${ }^{48}$ Sistani's website reproduces the handwritten authorization of his distinguished teachers to exercise his own reasoning (ijtih $\bar{a} d)$ in interpreting scripture (fig. 4), hugely significant given the controversy over the qualifications of some of his rivals, such as Fadlallah. ${ }^{49}$

It is not that Sistani is especially conservative or "traditionalist" (taqlìd $\vec{\imath}$ ) in favoring the digital calligraphy of scanned manuscript, and indeed the commonly perceived traditionalism of his jurisprudence is exaggerated. ${ }^{50}$ With regard to digital technology Sistani's offices have in any case been pioneers, the first to bring the Internet to the seminaries of Qom in 1996. Sistani's website is itself a massive resource (Khalaji 2006: 10; Rahimi 2007: 7-8). Furthermore, the need to anchor opinion to person is shared, as is the recourse to the "neo-calligraphy" of scanning technology to do so. To return to Ayatollah Fadlallah, the transcriptions of his lectures, already discussed, are always authenticated by Fadlallah in a preface to the volume. In the more recent volumes that preface is in the sayyid's own hand, accompanied by his signature and seal, scanned in (fig. 5). So, too, Ayatollah Khamene'i, widely followed in Lebanon due to the popularity of the Iranian-backed Hezbollah, who acknowledge him as the "guardian jurisprudent" (al-wali al-faqīh); he has his signature and seal scanned onto the cover of his risālah 'amalīyah, his handbook for his followers

48 This would seem to be the standard procedure (Visser 2006: 26).

49 Besides that of Ayatollah Khu'i, shown in figure 3, the website also reproduces the certificates of Ayatollahs Hilli and Tehrani: http://www.sistani.org/local.php?modules=nav\&nid=1, accessed 1 June 2009.

50 Sistani's political discourse is, while sparing, highly sophisticated. Noah Feldman (2004: 40), professor of law and constitutional advisor to the Coalition Provisional Authority in Iraq, characterizes his constitutional fatwa as "pure democratic theory with nary a reference to Islamic legal texts ... Its conclusion and reasoning were, indeed, essentially indistinguishable from those of any competent international lawyer." Hamid al-Khaffaf told me that prior to issuing the fatwa Sistani had undertaken wide-ranging studies of other constitutions, especially those of postoccupation states such as Japan and Afghanistan. Sistani's positions on women's political rights, as stated to Der Spiegel, for instance (Khaffaf 2007: 99), are far from reactionary. And Sistani and those around him have most certainly engaged with medical and scientific advance: witness his son Sayyid Muhammad Rida Sistani's volumes on contraception and assisted reproduction (M. R. Sistani 2004; 2007; and see Clarke 2009). 


$$
\text { بسم الله الرحمن الرحيم }
$$

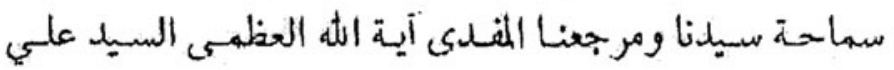

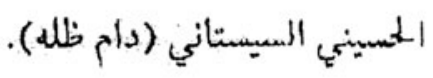

$$
\text { السلام عليكم و.رحهة الهه وبركاته وبعل : }
$$

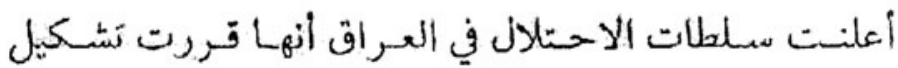

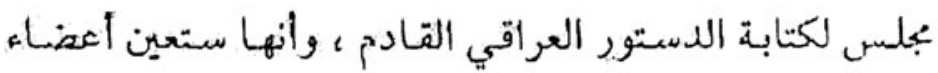

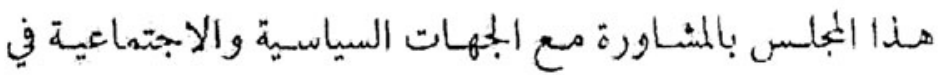

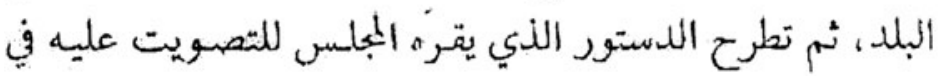

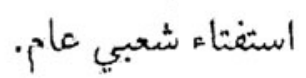

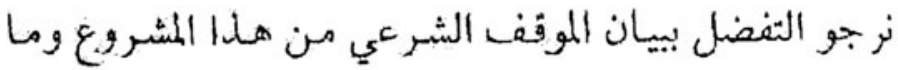

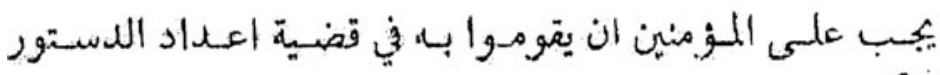
العرافئي.

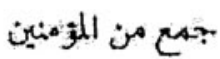

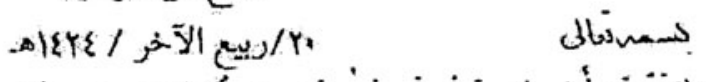

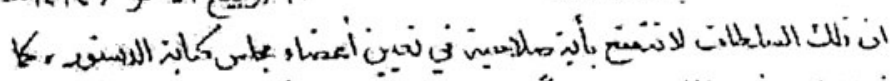

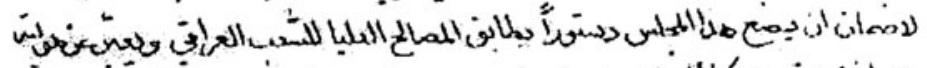

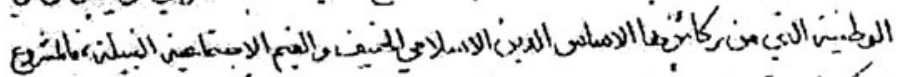

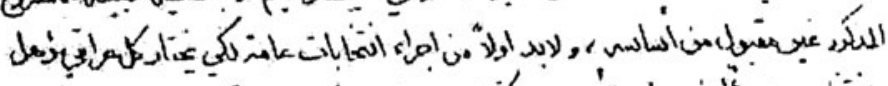

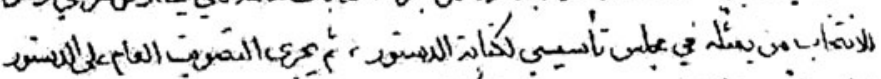

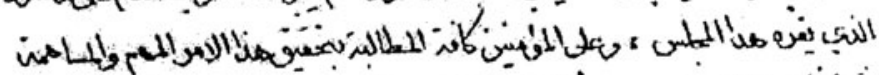

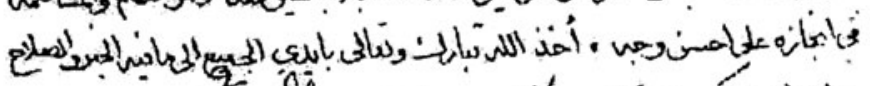

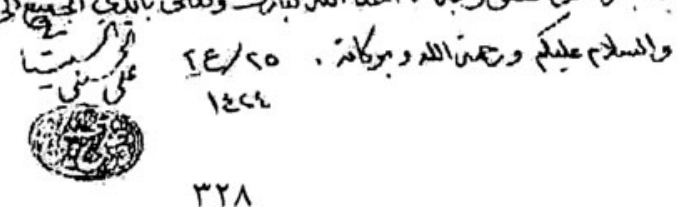

FIGURE 2 Ayatollah Sistani's fatwa on the Iraqi constitution, hand-written below the question it answers, with Sistani's signature and seal (Khaffaf 2007: 328). Reprinted with permission. 


\section{WWW.SISTANI.ORG}

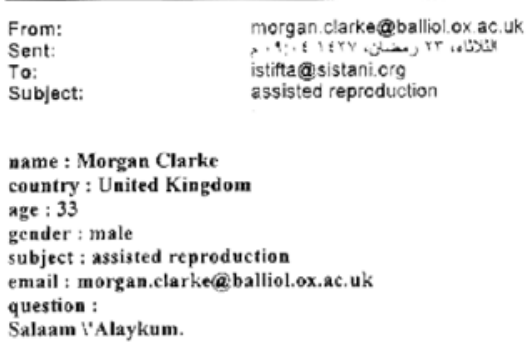

Your ruling on artificial insemination by a man other than a husband is clear: it is forbidden. What is your ruling on the use of an egg other than that of the wife: is it allowed in itself? Is it allowed if the husband marries the provider of the egg? Is it allowed to hire the womb of another woman? In these cases, who should be considered the mother: the provider of the egg, or the woman who carries the foetus in her womb?

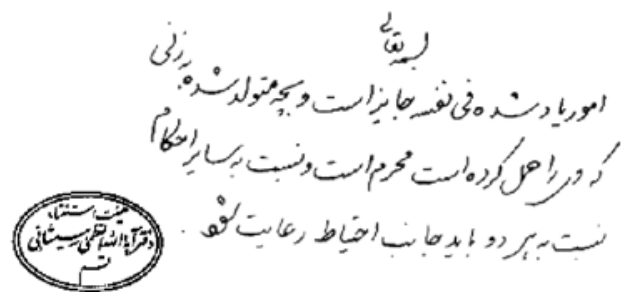

FIGURE 3 Correspondence between the author and Ayatollah Sistani's website offices in Qom, with the reply to the author's question handwritten below it and with the office's seal, sent as a GIF attachment by email.

(Khamene'i 2006), and so do the other marja's (fig. 6). ${ }^{51}$ Audio and video, compelling indices of identity, can also be posted on websites, as they are on Fadlallah's. Indeed I would argue that the need and demand for such personalization of authority is greater today than before, given the possibility now of circumventing the local clerical expert or "representative" by accessing remotely, but with the veneer of immediacy, a great authority rendered familiar through ubiquitous mass media. The relationship between lay follower and their chosen authority can be perceived, desired, and portrayed as more, rather than less, personal in the neo-calligraphic age. ${ }^{52}$

51 As will be apparent, none of the seals are quite the "calli-graphy," the beautiful writing, of Messick's Imamic seals (1993: 242). They seem more functional, the personal seals confined simply to the name, without title, of the authority concerned.

52 One's choice of marja' is frequently said to be a personal (shakhsì) matter, not spoken of lightly (to foreign ethnographers at any rate), and often manifestly held with deep affection, and even "love" (hubb). One might discern a (competitive) "politics of immediation" (Allen 2009, after Mazzarella 2006) at play here as elsewhere in the contemporary media-saturated public sphere. Ayatollah Fadlallah's website, for instance, proudly records its own early inception (in 1997, just after Sistani's) and states the aim of the radio station as "entering into every home in 


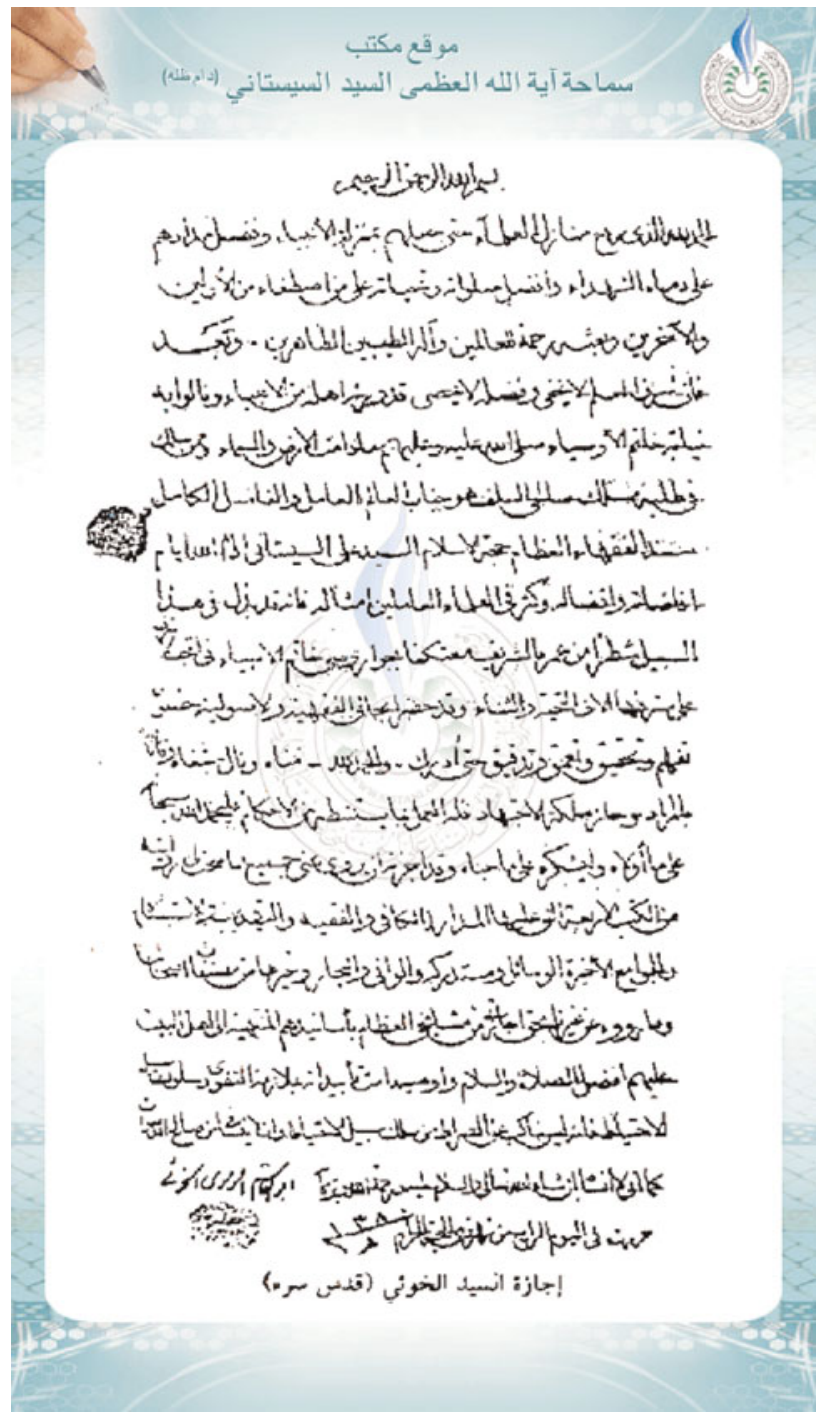

FIGURE 4 Ayatollah Sistani's certificate from his teacher Ayatollah Abu-1-Qasim al-Khu'i confirming his status as a mujtahid (a scholar capable of independently formulating Islamic jurisprudence), posted on Sistani's website: http://www.sistani.org/local.php?modules=nav\&nid=1, accessed 1 June 2009. Reprinted with permission.

Lebanon and if possible outside Lebanon" (http://arabic.bayynat.org.lb/sira/moassasat.htm, accessed 13 Oct. 2009). 


\section{تقريظ معاحة آية الله العظى السيد محمد حسين فضل الله (دام ظله):} بسم الثه الرحنالرهيم.

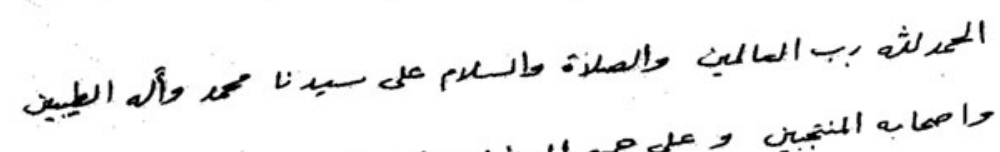

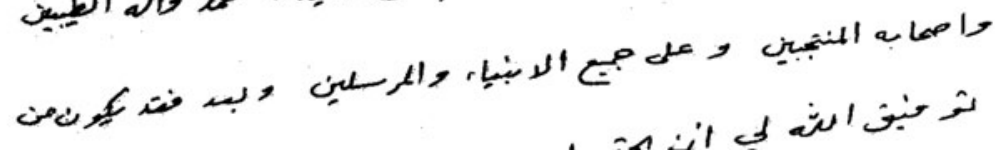

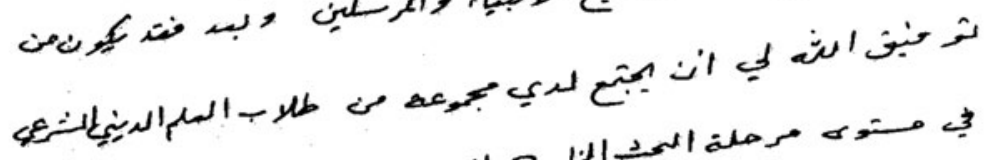

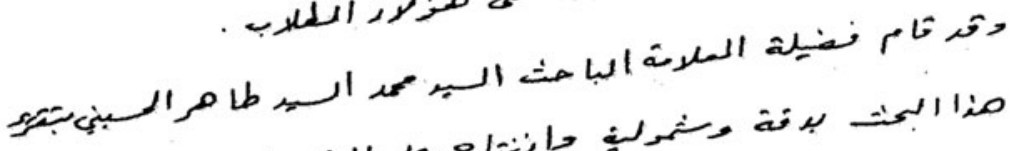

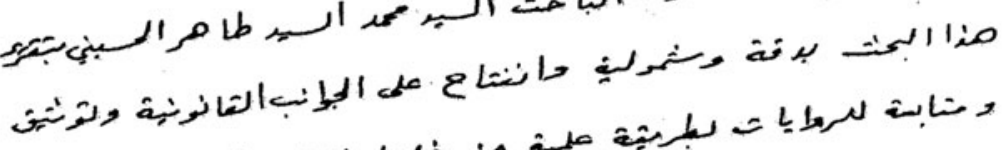

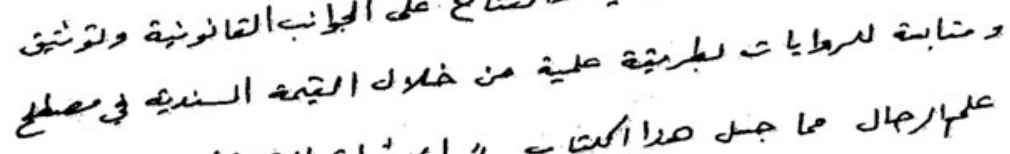

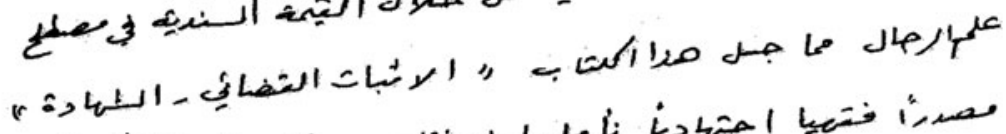

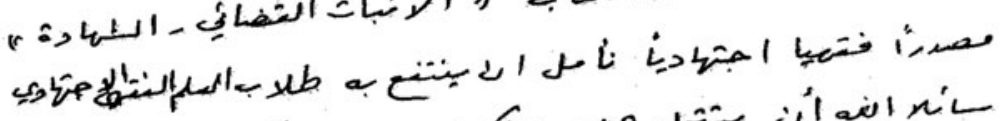

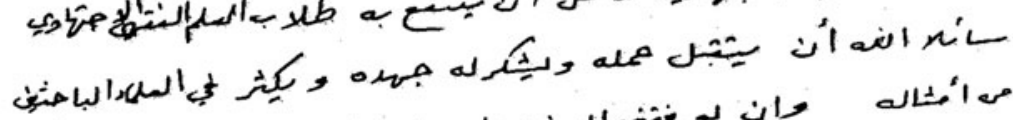

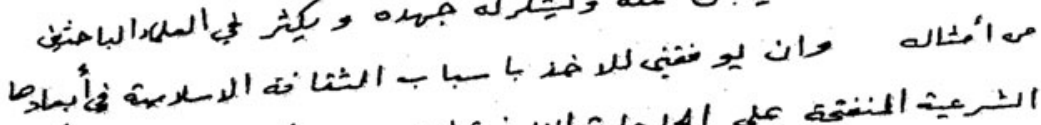

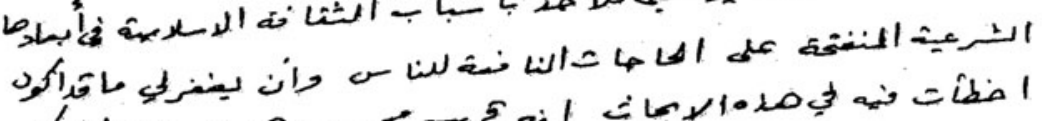
1

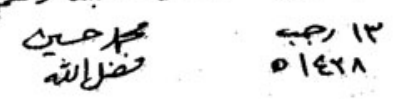

FigurE 5 Ayatollah Fadlallah's hand-written preface to one of the editions of his lectures (Husayni 2007a). Reprinted with permission.

The differences between these authorities lie elsewhere, and then often as a matter of emphasis rather than of kind. Fadlallah, explicitly more activist (haraki, "dynamic"), and more closely associated with Islamist and 


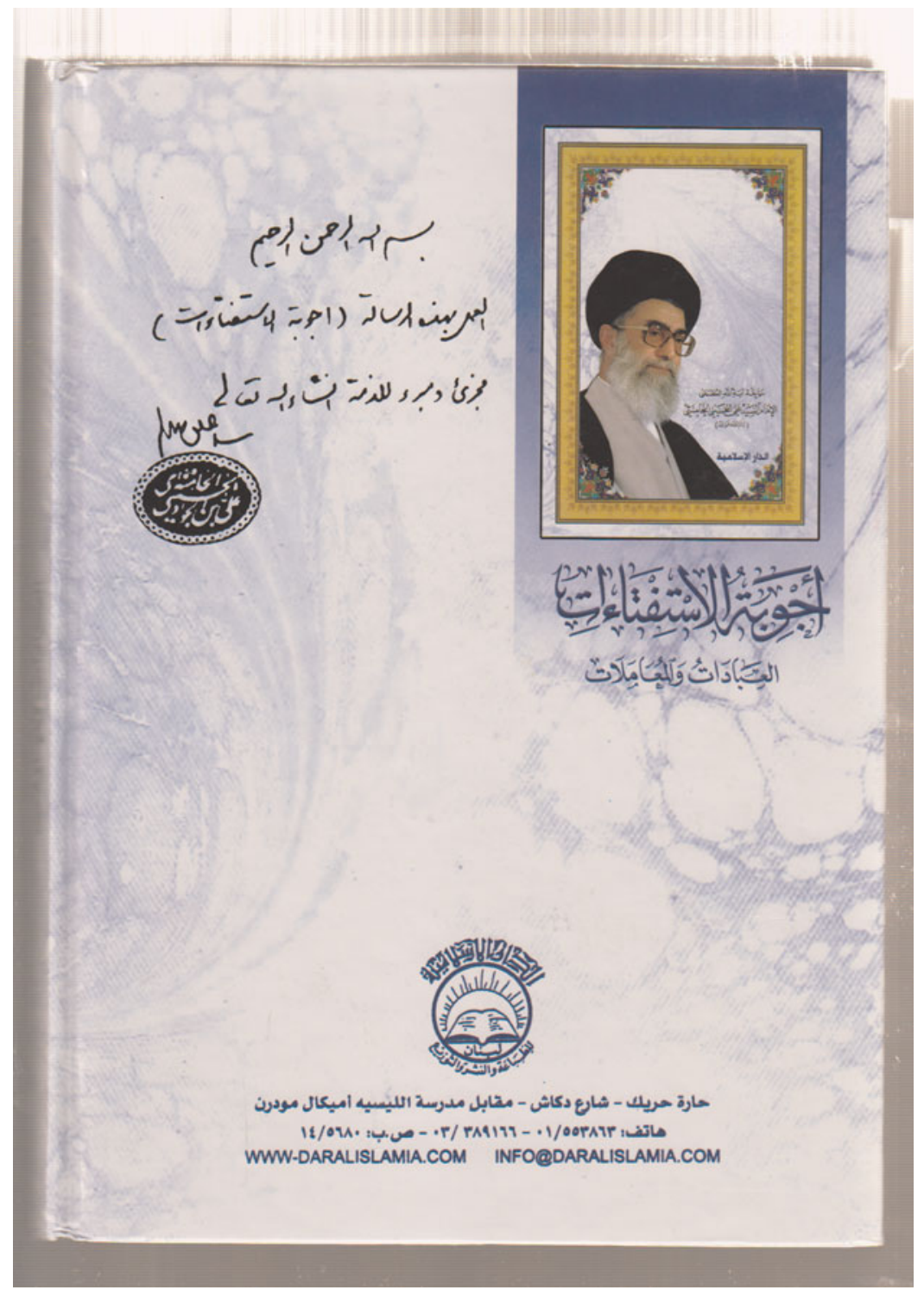

FIGURE 6 Back cover of Ayatollah Khamene'i's fatwa collection (Khamene'i 2006) featuring a hand-written message and his seal, as well as his photograph. Reprinted with permission.

revolutionary Shiism, engages with the press. Sistani, resolutely disengaged from mundane politicking (if not politics) and the Khomeinist school, seeks to preserve a certain distance. Khalaji (2006: 12), who maintains that giving 
interviews to journalists is a tradition of Qom and not of Najaf, invokes the notion of the haram, separated sacred space, or in his words "a special distance ... an indication of the power order. A religious leader should not be publicized, especially by modern technology, because in that case he loses his religious pomp and spiritual glory." $" 53$ Sistani's office receives requests from followers eager for permission to put up pictures of the sayyid on shop doors or the walls of official buildings and government schools, because, "As the Prophet said, 'gazing at the face of the learned is an act of worship," and, "It might guide someone or stop his sinning when he sees the banner of a luminary ['alam] among God's religious scholars." But the office refuses them point blank (Khaffaf 2007: 55, 137). Fadlallah would say the same, and his picture is not a feature of Beirut's landscape as are those of Sayyid Hasan Nasrallah, secretary general of Hezbollah, or Ayatollahs Khomeini and Khamene'i of Iran (Deeb 2006: 50-59). ${ }^{54}$ But it is harder to imagine Associated Press asking of Fadlallah, as they do of Sistani, "Why do we not hear more of your voice?" It may be a related difference in national religious culture that leaves it to a Lebanese religious association, the Husayni club of Nabatiyah, to ask Sistani's son, Sayyid Muhammad Rida Sistani, "Why is the media presence of the marja 'iyah so weak?"55 Khaffaf conceded to me, "the sayyid is very sparing" (muqill jiddan). But the marja' is a very special kind of figure, the Impeccable Imam's deputy and nominally near infallible himself, and one does not throw that into jeopardy lightly. And such economy brings strength: "Does Sayyid Sistani have an army or a militia? No, he just has his word [kalimah]. If Sayyid Sistani speaks his word, millions follow it. This strength comes from not talking all the time. What is the use of the marja ' if he issues a statement or a fatwa every day?" (Of course, another school of opinion might ask, "What is the use of the marja' if he doesn't speak?") In any case, as Khaffaf noted, it is only Sistani's "political" fatwas that are rare, and a perusal of the online archive on his website reveals that the number of petitions his offices answer on "religious" matters is vast. The conflict being played out here between the piety required to be a marja ' and the worldliness the role requires is an old one that resonates beyond this particular, Islamic setting. It leads some qualified candidates to eschew the role (Khalaji 2006: 2, n. 4; Clarke 2009: 140). The mufti takes on the responsibility before God for those decisions the layman takes in accordance with his fatwas.

\footnotetext{
53 Cf. Messick (1993: 165-73) on such ideologies of separation and awe (haybah) regarding the judiciary in 1970 s North Yemen.

54 Interestingly, in the editions I have to hand, at least, Fadlallah's risālah 'amalīyah does not bear his photograph, while those of Sistani and, less surprisingly, Khamene'i do (see fig. 6).

55 Khaffaf 2007: 72-73, 94-95. The reply to the first is that Sistani prefers to leave politics to politicians, and to the second that he has a firm policy of not cooperating with the media, except where absolutely necessary: it is for the faithful to be mindful of the media's lack of professionalism.
} 
Such "imitation [taqlīd]," Ayatollah Fadlallah's eldest son told me in a neat play on words, "is a necklace [qilādah] round the marja"s neck- he must put their problems upon his own shoulders." 56

\section{CONCLUSION}

Many of the patterns of Messick's "calligraphic" characterization of shari'ah discourse endure, albeit constituted in different ways through modern digital technology, what I have called here "neo-calligraphy," in both a literal reference to scanned manuscript and a more general, metaphorical one to the new ways in which personalized jurisprudence can be formulated and communicated in new contexts. Rather than a simple, if painful transition from "calligraphy" to "modernity," the ocean of open interpretation grows ever larger, and the evermultiplying claims to authoritative opinion still need to be tied to recognized individuals in order to stand for something meaningful. That meaningful stand can be more or less vociferously asserted. But to dam the ocean, to harness the shari'ah within the institutions of the impersonal state, or indeed any form of official monopoly, is nigh impossible. Like the Internet itself (Fandy 1999), it leaks out from between the fingers, a sort of "neo-calligraphic not-state," or "anti-state." Religious authorities of the stature of Fadlallah and, more especially, Sistani speak with an independent voice that is either hard to ignore or, as in Sistani's case, has to be heard. I do not mean to imply that either Fadlallah or Sistani are against the state, per se: both put great weight on the importance of upholding "public order" (al-nizām al-'àmm). ${ }^{57}$ Rather, as Messick has pointed out, shari'ah discourse simply has a different grammar from that of the bureaucratic state. And perhaps, in the final analysis, that is what makes it so appealing for the religiously, and the academically minded.

\section{REFERENCES}

Abisaab, R. 2006. The Cleric as Organic Intellectual: Revolutionary Shi'ism in the Lebanese Hawzas. In H. Chehabi, ed., Distant Relations: Iran and Lebanon in the Last 500 Years. London: Centre for Lebanese Studies in association with I. B. Tauris, 231-58.

Ajami, F. 1986. The Vanished Imam: Musa al-Sadr and the Shia of Lebanon. London: I. B. Tauris.

Allen, L. 2009. Martyr Bodies in the Media: Human Rights, Aesthetics, and the Politics of Immediation in the Palestinian Intifada. American Ethnologist 36, 1: 161-80.

Asad, T. 1986. The Idea of an Anthropology of Islam. Occasional paper. Washington,

D.C.: Center for Contemporary Arab Studies, Georgetown University.

${ }^{56}$ Interview with Sayyid 'Ali Fadlallah, 21 June 2008.

${ }^{57}$ Fadlallah holds that a visa amounts to a contract between, for example, a Lebanese Shiite emigrant and their host country, binding them to abide by its laws (interviews with Sayyid 'Ali Fadlallah, 12 June 2008; Shaykh Husayn al-Khishn, 4 June 2008; and Shaykh Muhsin 'Atwi, 21 Mar. 2008). 
Asad, T. 2003. Formations of the Secular: Christianity, Islam, Modernity. Stanford: Stanford University Press.

Aziz, T. 2001. Fadlallah and the Remaking of the Marja'iya. In L. Walbridge, ed., The Most Learned of the Shi 'a: The Institution of the Marja 'Taqlid. Oxford: Oxford University Press, 205-15.

Berque, J. 2001 [1944]. Essai sur la méthode juridique maghrébine. Reprinted in J. Berque (A. Mahé, ed.), Opera Minora, vol. 1 (of 3), Anthropologie juridique du maghreb. Paris: Éditions Bouchène, 273-358.

Bourdieu, P. 1997. De la maison du Roi à la raison d'État: Un modèle de la genèse du champ bureaucratique. Actes de la recherche en sciences sociales 118: 55-68.

Bremer, P. 2006. My Year in Iraq: The Struggle to Build a Future of Hope. New York: Simon and Schuster.

Carruthers, M. 1990. The Book of Memory: A Study of Memory in Medieval Culture. Cambridge: Cambridge University Press.

Clarke, M. 2007. Children of the Revolution: Ayatollah Khamene'i's "Liberal" Views on in Vitro Fertilisation. British Journal of Middle Eastern Studies 34, 3: 287-303.

Clarke, M. 2009. Islam and New Kinship: Reproductive Technology and the Shariah in Lebanon. Oxford: Berghahn.

Cole, J. 2006. The Ayatollahs and Democracy in Iraq. ISIM Paper 7. Amsterdam: Amsterdam University Press.

Davison, R. 1963. Reform in the Ottoman Empire, 1856-1876. Princeton: Princeton University Press.

Deeb, L. 2006. An Enchanted Modern: Gender and Public Piety in Shi 'i Lebanon. Princeton: Princeton University Press.

Eickelman, D. 1978. The Art of Memory: Islamic Education and Its Social Reproduction. Comparative Studies in Society and History 20, 4: 485-516.

Eickelman, D. 1992. Mass Higher Education and the Religious Imagination in Contemporary Arab Societies. American Ethnologist 19, 4: 643-55.

Eickelman, D. and J. Anderson, eds. 1999. New Media in the Muslim World: The Emerging Public Sphere. Bloomington: University of Indiana Press.

El-Ghoul, A. 2004. Delivering in the Toughest of Times. Daily Star (Beirut), 25 Oct.

Fadlallah, Muhammad Husayn. 1998. Al-fatāwā al-wādihah. 2d ed. Beirut: Dar al-Malak.

Fadlallah, Muhammad Husayn. 2002-2003. Fiqh al-sharīah. 3 vols. 6th ed. Beirut: Dar al-Malak.

Fadlallah, Muhammad Husayn. 2005a. Al-masā'il al-fiqhīyah. 2 vols. 10th ed. Beirut: Dar al-Malak.

Fadlallah, Muhammad Husayn. 2005b. Dunyā al-mar'ah. 6th ed. Beirut: Dar al-Malak.

Fadlallah, Muhammad Husayn. 2009. Al-masā'il al-fiqhīyah: al-'ibādāt. New ed. Beirut: Dar al-Malak.

Fandy, M. 1999. Cyber-Resistance: Saudi Opposition between Globalization and Localization. Comparative Studies in Society and History 41, 1: 124-47.

Feldman, N. 2004. What We Owe Iraq: War and the Ethics of Nation Building. Princeton: Princeton University Press.

Firhan, Jihad, ed. 2007. Fiqh al-hajj: Taqrīran li-abhāth sayyid-nā al-ustādh Samāhat $\bar{A}$ àt Allāh al-'Uzmā al-Sayyid Muhammad Husayn Fadl Allāh. Vol. 1. Beirut: Dar al-Malak.

Fischer, M. 1980. Iran: From Religious Dispute to Revolution. Cambridge, Mass.: Harvard University Press.

Foucault, M. 1979. What is an Author? In J. Harari, ed., Textual Strategies: Perspectives in Post-Structuralist Criticism. Ithaca, N.Y.: Cornell University Press, 141-60. 
Fraenkel, B. 1992. La signature: Genèse d'un signe. Paris: Gallimard.

Fraenkel, B. and D. Pontille. 2006. La signature au temps de l'electronique. Politix 74, 2: $103-21$.

Gleave, R. 2007a. Conceptions of Authority in Iraqi Shi'ism: Baqir al-Hakim, Ha'iri and Sistani on Ijtihad, Taqlid and Marja'iyya. Theory, Culture and Society 24, 2: $59-78$.

Gleave, R. 2007b. The Qadi and the Mufti in Akhbari Shi'i Jurisprudence. In P. Bearman, W. Heinrichs and B. Weiss, eds., The Law Applied: Contextualizing the Islamic Shari 'a. London: I. B. Tauris, 235-58.

Griffel, F. 2007. Introduction. In F. Griffel and A. Amanat, eds., Shari 'a: Islamic Law in the Contemporary Context. Stanford: Stanford University Press, 1-19.

Hamiyah, Khanjar, ed. 2000. Fiqh al-mawārīth wa-l-farā'id-bahth fiqhī muqārin: Taqrīran li-abhāth sayyid-nā al-ustādh Samāhat Āyāt Allāh al- 'Uzmā al-Sayyid Muhammad Husayn Fadl Allāh. 2 vols. Beirut: Dar al-Malak.

Hamiyah, Siham. 2004. Al-mar'ah fì-l-fikr al-falsafì al-ijtimà 'c̀ al-islāmī: Dirāsah fì fikr al-Sayyid Muhammad Husayn Fadl Allāh. Beirut: Dar al-Malak.

Hart, K. 2007. Money is Always Both Personal and Impersonal. Anthropology Today 23, 5: $12-16$.

Hasani, Salim al-. 1994. Al-ma'ālim al-jadīdah li-l-marja 'īyah al-shī'ìyah: Dirāsah wa-hiwār ma' Āyāt Allāh al-Sayyid Muhammad Husayn Fadl Allāh. Beirut: Dar al-Malak.

Hirschkind, C. 2006. The Ethical Soundscape: Cassette Sermons and Islamic Counterpublics. New York: Columbia University Press.

Husayni, Muhammad al-, ed. 2002. Fiqh al-sharikah: Taqrīran li-abhāth al-marja" al-dīnī Āyāt Allāh al-'Uzmā al-Sayyid Muhammad Husayn Fadl Allāh. Beirut: Dar al-Malak.

Husayni, Muhammad al-, ed. 2007a. Al-ithbāt al-qadā't-al-shahādah: Taqrīran li-abhāth al-marja' al-dīn̄ Samāhat Āyāt Allāh al-'Uzmā al-Sayyid Muhammad Husayn Fadl Allāh. Beirut: Dar al-Malak.

Husayni, Muhammad al-. 2007b. Murtakizāt asāsīyah fī al-minhaj al-fiqhī 'ind al-Sayyid Fadl Allāh. In M. al-Husayni, eds., Al-ithbāt al-qadā' '-al-shahādah: taqrīran li-abhāth al-marja' al-dīnī Samāhat Āyāt Allāh al- 'Uzmā al-Sayyid Muhammad Husayn Fadl Allāh. Beirut: Dar al-Malak, 9-25.

Khaffaf, Hamid, ed. 2007. Al-nusūs al-sādirah 'an Samāhat al-Sayyid al-Sīstān̄̄ fi-l-mas 'alah al- 'irāqīyah. Beirut: Dar al-Mu'arrikh al-'Arabi.

Khalaji, M. 2006. The Last Marja: Sistani and the End of Traditional Religious Authority in Shiism. Policy Focus 59. Washington, D.C.: Washington Institute for Near East Policy.

Khamene'i, 'Ali al-. 2006. Ajwibat al-istiftā'āt: Al-'ibādāt wa-l-mu'ämalāt. 6th ed. Beirut: al-Dar al-Islamiyah.

Khishn, Husayn al-, ed. 2007. Fiqh al-qadā': Taqrīran li-abhāth al-marja 'al-dīn̄ Āyat Allāh al-'Uzmā al-Sayyid Muhammad Husayn Fadl Allāh. Vol. 2. Beirut: Dar al-Malak.

Latour, B. 2004. La fabrique du droit: Une ethnographie du Conseil d'État. Paris: La Découverte.

Liebesny, H. 1975. The Law of the Near and Middle East. Albany: State University of New York Press.

Luizard, P.-J. 2003. Les fatwas 'politiques' de l'Ayatollah al-Sîstânî (Septembre 2002Octobre 2003). Maghreb/Machrek 178: 109-21.

Mallat, C. 1988. Shi'i Thought from the South of Lebanon. Papers on Lebanon 7. Oxford: Centre for Lebanese Studies. 
Mallat, C. 1993. The Renewal of Islamic Law: Muhammad Baqer as-Sadr, Najaf, and the Shi 'i International. Cambridge: Cambridge University Press.

Mazzarella, W. 2006. Internet X-Ray: E-Governance, Transparency, and the Politics of Immediation in India. Public Culture 18, 3: 473-505.

Mervin, S. 2000. Un réformisme chiite: Ulémas et lettrés du Jabal 'Âmil (actuel LibanSud) de la fin de l'Empire ottoman à l'indépendance du Liban. Paris: Karthala.

Mervin, S. 2001. The Clerics of Jabal 'Amil and the Reform of Religious Teaching in Najaf since the Beginning of the 20th Century. In R. Brunner and W. Ende, eds., The Twelver Shia in Modern Times: Religious Culture and Political History. Leiden: Brill, 79-86.

Messick, B. 1993. The Calligraphic State: Textual Domination and History in a Muslim Society. Berkeley: University of California Press.

Messick, B. 1996. Media Muftis: Radio Fatwas in Yemen. In M. K. Masud, , B. Messick, and D. S. Powers, eds., Islamic Legal Interpretation: Muftis and Their Fatwas. Cambridge, Mass.: Harvard University Press.

Messick, B. 2008. Shari‘a Ethnography. In P. Bearman, W. Heinrichs, and , B. Weiss, eds., The Law Applied: Contextualizing the Islamic Shari 'a. London: I. B. Tauris, 173-93.

Meyer, B. and A. Moors, eds. 2006. Religion, Media, and the Public Sphere. Bloomington: University of Indiana Press.

Milbank, D. 2004. After Outcry, Rumsfeld Says He Will Sign Condolence Letters. Washington Post (Washington, D.C.), 19 Dec.

Mottahedeh, R. 1985. The Mantle of the Prophet: Learning and Power in Iran. New York: Pantheon.

Norton, R. 1987. Amal and the Shi 'a: Struggle for the Soul of Lebanon. Austin: University of Texas Press.

Norton, R. 2007. Hezbollah: A Short History. Princeton: Princeton University Press.

Perry, T. 2009. Ayatollah Sees Obama Sincere in Muslim Message. Reuters, 9 Apr.

Rabbath, E. 1986. La formation historique du Liban politique et constitutionnel: Essai de synthèse. Beirut: Librairie Orientale.

Rahimi, B. 2007. Ayatollah Sistani and the Democratization of Post-Ba'athist Iraq. Special Report 187. Washington, D.C.: United States Institute of Peace.

Rosiny, S. 2001. "The Tragedy of Fatima al-Zahra" in the Debate of Two Shiite Theologians in Lebanon. In R. Brunner and W. Ende, eds., The Twelver Shia in Modern Times: Religious Culture and Political History. Leiden: Brill, 207-19.

Sankari, J. 2005. Fadlallah: The Making of a Radical Shi ite Leader. London: Saqi.

Shaery-Eisenlohr, R. 2008. Shi'ite Lebanon: Transnational Religion and the Making of Religious Identities. New York: Columbia University Press.

Shakhuri, Ja'far al-. 1996 (vol. 1) and 2002 (vol. 2). Kitāb al-nikāh: Taqrīran li-bahth Samāhat Āyāt Allāh al-'Uzmā al-Sayyid Muhammad Husayn Fadl Allāh. Beirut: Dar al-Malak.

Shalakany, A. 2001. Between Identity and Redistribution: Sanhuri, Genealogy and the Will to Islamise. Islamic Law and Society 8, 2: 201-44.

Sistani, 'Ali al-. 2000. Al-figh li-l-mughtaribīn. Beirut: Dar al-Mu'arrikh al-'Arabi.

Sistani, 'Ali al-. 2002. Minhāj al-sālihīn. 3 vols. Qom: Maktabat Fadak.

Sistani, 'Ali al-. 2007. Al-'urwah al-wuthqā li-Āyat Allāh al-'Uzmā al-Sayyid Muhammad Kāzim al-Yazd̄̄ ma' ta 'ī̄q Samāhat Āyat Allāh al-'Uzmā al-Sayyid 'Al̄̄ al-Husaynī al-Sīstān̄̄ (2 vols.). Beirut: Dar al-Mu'arrikh al-'Arabi.

Sistani, Muhammad Rida al-. 2004. Wasā’il al-injāb al-sinā' '̄yah: Dirāsah fiqhīyah. Beirut: Dar al-Mu'arrikh al-'Arabi.

Sistani, Muhammad Rida al-. 2007. Wasā’il al-man' min al-injāb (dirāsah fiqhīyah): Wa-yali-hā bahth hawl jinābat al-mar'ah bi-ghayr al-muqārabah. Beirut: Dar al-Mu'arrikh al-'Arabi. 
Starrett, G. 1998. Putting Islam to Work: Education, Politics, and Religious Transformation in Egypt. Berkeley: University of California Press.

Sukariyah, Mona. 2007. 'An sanawāt wa-mawāqif wa-shakhsīyāt: Hākadhā tahaddath... hākadhā qāl (interviews with Ayatollah Muhammad Husayn Fadlallah). Beirut: Dar al-Nahar.

Visser, R. 2006. Sistani, the United States and Politics in Iraq: From Quietism to Macchiavellianism? NUPI paper 700. Oslo: Norwegian Institute of International Affairs.

Walbridge, L. 2001a. Introduction: Shi'ism and Authority. In L. Walbridge, ed., The Most Learned of the Shi 'a: The Institution of the Marja 'Taqlid. Oxford: Oxford University Press, $3-13$.

Walbridge, L. 2001b. The Counterreformation: Becoming a Marja' in the Modern World. In L. Walbridge, ed., The Most Learned of the Shi' $a$ : The Institution of the Marja'Taqlid. Oxford: Oxford University Press, 230-46.

Zaman, M. 2002. The Ulama in Contemporary Islam: Custodians of Change. Princeton: Princeton University Press. 